\title{
ECONOMICS
}

\section{Does Education Affect Time Preference? Evidence from Indonesia}

by

\section{Dawoon Jung}

Korea Institute of Public Finance

Tushar Bharati

Economics Discipline, Business School, University of Western Australia

and

Seungwoo Chin

Ministry of Finance and Strategy, Korea 


\title{
Does Education Affect Time Preference? Evidence from Indonesia.
}

\author{
Dawoon Jung, Tushar Bharati, and Seungwoo Chin *
}

June 30, 2019

\begin{abstract}
The paper examines the causal effect of education on time preference. To define our measure of time preference, we use responses to hypothetical questions involving inter-temporal trade-offs from the Indonesian Family Life Survey. We instrument years of education with exposure to the Indonesian INPRES primary school construction program of the 1970s that caused exogenous variations in the cost of going to school. The local average treatment effect of the program was a nine percentage point decrease in the probability of a female respondent choosing the most impatient response for every additional year of schooling. The results are robust to alternative definitions of the time preference measures but sensitive to changes in samples and specifications. The findings add to the evidence on the endogeneity of individual preferences parameters that are often taken to be constant in neoclassical economics.
\end{abstract}

JEL Classification Codes: D01, D90, I25

Keywords: Time preference, patience, education, Indonesia

*Jung: Korea Institute of Public Finance. Email: dwjung@kipf.re.kr. Bharati: University of Western Australia Business School. Email: tushar.bharati@uwa.edu.au. Chin: Ministry of Finance and Strategy, Korea. Email: swchin1983@korea.kr. We are grateful to Esther Duflo for sharing the INPRES school construction data with us. This paper has benefited substantially from the feedback provided by Rakesh Banerjee, Daniel Bennett, Riddhi Bhowmick, Isabelle Brocas, Lisa Cameron, Esther Duflo, Pascaline Dupas, Michael Kremer, Craig McIntosh, Edward Miguel, Teresa Molina, Kaivan Munshi, Jeff Nugent, Anant Nyashadham, Martin Ravallion, Juan Saavedra, Manisha Shah, John Strauss, Michael Callen, participants at the Ninetieth Annual Western Economic Association International Conference (Hawaii, 2015), the Population Association of America Annual Meeting (Washington D.C., 2016), UNU WIDER's Human Capital Development Conference (Helsinki, 2016), California State University, Long Beach (2017), and two anonymous referees. All errors are our own. 


\section{Introduction}

This paper uses information from the Indonesia Family Life Survey (IFLS) to estimate the causal effect of education on individual time preference. Time preference refers to the relative valuation placed on a good delivered immediately compared to its valuation on a later date. The rate of time preference (or time discounting) is $-\log \left(\beta_{T}\right)$, where $\beta_{T}$ is the discount factor ranging from 0 to $1 .{ }^{1}$ For individuals, key decisions, such as savings or investments in health and education, that affect the important outcomes like employment, income, longevity, and overall welfare depend on the individual's level of patience (Stigler and Becker (1977); Bickel et al. (1999); Golsteyn et al. (2014); Non and Tempelaar (2016)). At a macro-level, time preference, through its impact on saving and investment, is crucially linked to economic growth (Callen (2015); Dohmen et al. (2015)).

Despite its ubiquity and importance, previous research has paid little attention to the determinants of time preference (Anderson et al. (2004)). In the neoclassical theory, time preference is often assumed to be a static economic primitive, fixed over time for individuals and, often, constant across individual agents (Meier and Sprenger (2015)). Economists have often questioned this assumption. ${ }^{2}$ While a theoretical framework for endogenous formation of time preference exists (Becker and Mulligan (1997)), the body of empirical evidence on the subject is limited. ${ }^{3}$ Some studies find causal impacts of natural disasters (Cassar et al. (2011); Callen (2015)) and conflict (Voors et al. (2012)) on time preference. But exposures to these extreme events are rare. The causal link between less extreme individual-specific circumstances and time preference have rarely been explored.

Recent research has found strong associations between educational attainment and time preference across countries (Falk et al. (2018)). There are at least two hypotheses regarding the relationship between education and time preference. First, individuals who are more patient might be more willing to sacrifice current labor market opportunities to obtain more schooling (Grossman (2006)) to improve future earnings. Second, schooling may infuse in individuals a higher level of patience by improving their forethought and planning and by making them more goal-oriented (Becker and Mulligan (1997); Oreopoulos and Salvanes (2011)). An empirical analysis of the causal effect of education on time prefer-

\footnotetext{
${ }^{1}$ We use the terms (inverse of) time preference, time discounting and patience interchangeably. This is a simplification. Readers interested in the distinction between the three terms should look at Frederick et al. (2002). The distinction is not crucial for this paper.

${ }^{2}$ The evidence from both observational and experimental studies suggest temporal instability of time preference even though we do not fully understand the reasons behind this instability (Meier and Sprenger (2015); Tanaka et al. (2010)).

${ }^{3}$ A large number of studies document the heterogeneity in individual time preferences along different socioeconomic dimensions like education, marriage, drinking/smoking behavior, age, gender, ethnicity, religion, language, household wealth, and income (Oreopoulos and Salvanes (2011); Kirby et al. (2002); Leigh (1986); Barsky et al. (1997); Rubalcava et al. (2009); Khwaja et al. (2007); Dohmen et al. (2011); Ng (2013); Lawrance (1991a); Pender (1996); Becker and Mulligan (1997); Chen (2013); H'Madoun and Nonneman (2012); Benjamin et al. (2016)); (Benjamin et al. (2010); Tanaka et al. (2010) and Golsteyn et al. (2014)). However, it is not clear from these studies whether it is the difference in these variables that drive difference in time preference or vice versa.
} 
ence, therefore, entails challenges such as reverse causality of the effect of time preference on education and selection into education. As a result, the research examining the causal effect of education in time preference is limited.

Bauer and Chytilová (2010) document an association between education and subjective discount rates of males in ten villages of the Mukono district in Southern Uganda. Perez-Arce (2017) leverages a college admission lottery in a University in Mexico City to show that individuals who entered college earlier were more patient by the time of the survey. However, as the authors acknowledge, issues related to sample selection, attrition, and violation of the instrumental variable exclusion restriction limit a causal interpretation of their findings. In a related randomized experiment, Alan and Ertac (2018) find that students in third and fourth grades of elementary schools in Turkey make more patient intertemporal decisions in incentivized experimental tasks when educated using a specially designed curriculum aimed at improving the ability to imagine their future selves and encouraging forward-looking behavior.

We add to this literature by examining the causal impact of an individual's education on time preference. To this end, we combine information on time preference and educational attainment of individuals surveyed in the Indonesian Family Life Survey (IFLS) with exogenous variation in the cost of attending school induced by a large-scale Indonesian primary school construction program. Duflo (2001) found that the program affected the educational attainment of those exposed. ${ }^{4}$. Using an instrumental variable approach, we find some evidence that suggests improvements in educational attainment of women due to the program led to an increase in their level of patience as measured by the hypothetical time-preference question in the IFLS. ${ }^{5}$ These findings add to the limited work on the long-term causal impact of education on time preference.

We also contribute to the mounting literature that demonstrates that life events can alter preferences (Cassar et al. (2011); Voors et al. (2012); Guiso et al. (2013); Callen et al. (2014); Callen (2015); Cameron and Shah (2015); Brown et al. (2017); Alan and Ertac (2018)). According to Heckman (2007), human capital production function takes both cognitive and non-cognitive ability as inputs. Our results show that education might affect human capital formation by affecting non-cognitive traits, like time preference, in addition to its effect through cognitive channels.

\footnotetext{
${ }^{4}$ Since Duflo (2001), many have replicated the findings (Duflo (2004); Akresh et al. (2018); Mazumder et al. (2019). Mazumder et al. (2019), like us, use information from the IFLS survey for their analysis.

${ }^{5}$ Since program exposure status fails to predict differences in educational attainment of males, we cannot make any such inference about the causal effect of education on time preference for males.
} 


\section{Background and Data}

\subsection{INPRES school construction program}

Beginning in 1973-74, the Indonesian government launched the Sekolah Dasar INPRES school construction program. The aim was to improve the education levels in the country by improving access to primary schools. Between 1973 and 1978, over 61,000 new primary schools were constructed. The program was focused on assisting first the districts with the lowest primary enrollment rates as per the 1971 census. As a result, there was a considerable variation in the school construction intensity across districts. Each district, on average, received two new schools. According to Duflo (2001, 2004), one newly constructed school, on an average, catered to approximately 500 children of ages 5 to 14 in 1971, and improved the educational attainment of exposed male children by 0.12 to 0.18 years of schooling. We borrow the information on intensity of school construction used in Duflo (2001). Intensity, here, is the number of newly constructed schools per 1,000 children in the district.

In Indonesia, individuals enroll in primary school when they are 6 to 7 years old and continue until they are 11-12 years old. Since the beginning of the program in 1973, children younger than 12 years in 1973, born in 1962 or after, were partially or entirely exposed to the INPRES program. Cohorts born before 1962 did not benefit from INPRES. Following Duflo (2001), we define cohorts born from 1968 to 1972 as exposed and those born between 1958 and 1962 as never-exposed or control cohorts. We drop from our sample those born between 1963 and 1967 because the extent of their exposure to the program is not clear. To causally identify the impact of the program on educational attainment, we examine the association between educational attainment of an individual and the interaction of the number of schools constructed in the individual's district and whether the individual was of the right age to have benefited from the program. Individuals who went to school after the program in districts where a lot of schools were constructed should have benefited more from the program compared to individuals who went to school before the program began or those in regions where few schools were constructed. Our specification, as we describe below, controls for a host of other individual- and community-level variables including those used in Duflo (2001).

We assume that an individual went to school in her district of birth. The IFLS also collects information on place of residence at age 12. Using this information, we find that around 93 percent of the individuals we study were in their birth districts at age 12. Our results (not presented here) do not change when we redo the analysis excluding those who were not in their birth districts at age 12 . 


\subsection{Indonesia Family Life Survey (IFLS)}

For our main analysis, we use the information on schooling attainments and time preference from the fifth wave (2014) of the Indonesian Family Life Survey. The IFLS is an ongoing longitudinal household survey conducted by RAND Corporation that began in 1993. The survey respondents represent about 83 percent of the Indonesian population and include over 50,000 individuals living in 13 of the 27 provinces in the country (Strauss et al. (2016)). It contains information on a wide variety of topics at the individual, the household and the community level. At the individual level, the survey collects information on health, education, employment, migration, and so on. The IFLS also collects information on individual time preference using hypothetical questions. Following Duflo (2001), those born in between 1968-1972 are considered to have been exposed to the INPRES school construction and those born in 1958-1962 form the control group. We use information from the most recent survey of an individual, using wave 5 when possible but wave 4 otherwise. Table 1 presents the summary statistics for this sample.

\subsection{Time Preference Measures}

We construct the main outcome variable of interest, a measure of time preference, based on two sets of hypothetical questions, module A and module B, included in the IFLS. The flowcharts in Figure 1 describes how these questions were administered. The monetary amounts are in Indonesian rupiah (IDR). ${ }^{6}$ The modules differ in the amounts of monetary rewards offered and the delay in future rewards. Module A (Module B) starts by asking respondents whether they will choose to receive one million rupiah today or one (half) million rupiah in one year. For each of these modules, if an individual chooses a smaller or equal amount of reward in the future than today, the individual exhibits zero or negative time discount rate (or a discount factor $>=1$ ). Following previous research on the topic, we drop these observations, $3 \%$ of the sample, from the analysis. ${ }^{7,8}$ As depicted in figure 1 , we categorize individuals into four different categories, from the most impatient to the most patient, depending on their willingness to sacrifice present reward for a higher future reward in their responses to these hypothetical questions. For our empirical exercises, we define a dummy variables TP-A (TP-B) that takes value ' 1 ' if a respondent chose the immediate reward throughout the time preference module A (B), '0' otherwise. This serves as our indicator measure of impatience.

There is a high degree of correlation between the two measures based on the two modules of time preference (Table A2). As per Table 1, a greater number of people prefer the immediate reward when they

\footnotetext{
${ }^{6} 1 \mathrm{USD}=11849.58$ IDR on December 31, 2014.

${ }^{7}$ Negative time discount rate could signal a variety of possibilities, from a strategic move of commitment to sheer irrationality to a simple inability to understand the questions. Unfortunately, given the information in the data set, it is not possible to distinguish between these possibilities. In any case, such behavior warrants separate analysis, and we drop those respondents from the sample.

${ }^{8}$ In Table A1, we show that a zero or negative time discount rate response is not systematically associated with education.
} 
have to wait longer for the delayed reward. This could be because respondents might find a future further away more difficult to visualize. ${ }^{9}$ Unfortunately, due to data limitations, we are unable to examine the sources of these differences further. Instead, we define a composite measure that combines information from responses to modules A and B using the factor analysis methodology. To check the robustness of our findings to different definitions of the time preference measures, we also use the time preference category from Figure 1 and an imputed value of the respondent's time preference for our analysis. The imputed value for a respondent's time preference measure is calculated using the method detailed in A.1.

The method used to elicit time preference in the IFLS survey is one of the three ways of measuring time preference. Some studies have attempted to infer time preference from real-life inter-temporal choices, such as daily caloric intakes, food expenditures, purchase of consumer durables, and so on (Lawrance (1991a); Shapiro (2005)). While this method has the advantage of using real-life choice that may reflect the rate at which individuals discount the future more accurately, such choices are affected by other behavioral and circumstantial factors like tastes, credit constraints, peer-effect, and so on. It is difficult to disentangle the role of time preference from these other factors using the information on choices alone.

The two alternatives are to collect information on individual time preference in experiments or field surveys using real or monetary rewards. Studies find that the two methods - real or hypothetical rewards provide similar estimates of individual time preference. ${ }^{10}$ Hamoudi (2006) and Dohmen et al. (2011) find that answers to hypothetical individual preference survey questions, like the ones used in the IFLS, are consistent with laboratory experiments estimates of these preference parameters and also actual behavior. We, too, find significant associations between the time preference measures and real-life behaviors, such as work-for-pay, savings, arisan participation, and, contraception usage. We report the associations in Table 2.

Multiple studies have found an association between smoking and time preference (Fuchs (1982); Khwaja et al. (2007); Ida and Goto (2009); Oreopoulos and Salvanes (2011); Kang and Ikeda (2014)). According to the World Bank, by 2012, 72\% of Indonesian males and 4\% of Indonesian females had smoked or used tobacco in his or her life. As is clear from column (1), all three measures of time preference (higher impatience) are significantly and positively associated with the smoking for men but not for women. Impatience has also been found to be associated with higher unemployment rates (DellaVigna and Paserman (2005); Ben Halima and Ben Halima (2009)). For our analysis, we consider

\footnotetext{
${ }^{9}$ According to (Loewenstein (2000)), long-term trade-offs involve a higher degree of forethought and planning.

${ }^{10}$ Coller and Williams (1999), in their experiment comparing the same monetary value of hypothetical and real rewards, found that discount rates inferred from the two procedures were not different once they controlled for censored data, demographic differences and heteroscedasticity. This finding is well supported by other papers (Johnson and Bickel (2002); Kühberger et al. (2002); Madden et al. (2003)).
} 
an individual to be working if he or she reports that he or she has worked for pay in the previous week or if he or she has received a wage/salary or made a non-zero business profit in the previous month. Consistent with previous literature, we find that impatient female respondents are less likely to work. By contrast, we find no significant relationship for male respondents.

Time discounting is known to affect savings (Ramsey (1928); Lawrance (1991b); Sutter et al. (2013)). As reported in Table 2, we too find that impatient individuals in our sample save less often and save lower amounts. In developing countries where credit markets are not as developed, rotating savings and credit associations (ROSCAs) are the most common informal financial institutions used for savings and insurance. ${ }^{11}$ In Indonesia, the ROSCAs are known as arisans. We find that impatient individuals are less likely to participate in arisans and other saving groups. Lawrance (1991a), Pender (1996), Tanaka et al. (2010) and Golsteyn et al. (2014) have found positive associations between income and patience in the United States, Vietnam, India and Sweden, respectively. Consistent with these studies we too find a positive relationship between patience and total income.${ }^{12}$ Impatient individuals may also be less likely to use contraception (DellaVigna and Paserman (2005)). The IFLS collects information on contraception usage for females. We find a significant association between time preference module A and contraceptive use but no significant association is found for time preference module B. In appendix tables A3 and A4, we report the association of these behavior measures with the time preference category and the imputed time preference value of the respondents, respectively.

This validation exercise suggests that time preference that affects intertemporal choices is reasonably well captured by the survey questions in the IFLS time preference module.

\section{Empirical Analysis}

If education was randomly assigned to individuals, we could have obtained unbiased estimates of the causal effect education on time preference by estimating a simple Ordinary Least Squares (OLS) equation. However, since educational attainment is not random, the OLS estimates may be biased due to reverse causality, omitted variables, or selection into education. ${ }^{13}$ To get to the causal estimates, we use the instrumental variable approach. Duflo (2001) finds that the large-scale primary school construction INPRES program of the 1970s had a significant positive causal impact on the education attainment of those exposed to the program. The conditional variation in the intensity of school construction was asso-

\footnotetext{
${ }^{11}$ ROSCAs are or were prevalent in both developing and developed countries around the world. For a detailed list of countries where ROSCAS have appeared, see the anthropological studies by Ardener (1964), and Bouman (1977).

${ }^{12}$ We define total income as the sum of wage salary, business profit, nonlabor income, and retirement pension income.

${ }^{13}$ For example, consider an individual born to impatient parents. The impatient parents might not be willing to make investments in the child's education since the returns to these investments would accrue in the future. Besides this, the child might also directly inherit the impatient nature of her parents.
} 
ciated with 0.12 to 0.18 extra years of education for those young enough to be exposed to the program. Following Duflo (2001), we combine the difference in intensity of the school construction program with the year of birth to construct a measure of exposure to the INPRES program that should predict the years of education of the individuals in our sample. To test whether individuals who went to school in districts with high intensity of school construction after the program saw an improvement in their educational attainment, we estimate the following specification

$$
1^{\text {st }} \text { stage }: S_{i d t}=\alpha+\left(T_{t} I_{d}\right) \rho+X_{i d t}+\delta_{d}+\tau_{t}+\epsilon_{i d t}
$$

where $S_{i d t}$ is the years of education for individual $i$ born in district $d$ in year $t . T_{t}$ is a dummy variable indicating whether the individual $i$ was young enough at the time of the program to have benefited from it. Following Duflo (2001), we assume that individuals born between 1968 and 1972 were exposed to the program while those born between 1958 and 1962 were too old to have benefited directly from the primary school construction program. $I_{d}$ denotes the intensity of the INPRES program in the district of birth $d$ measured by the number of school built per 1,000 children in the district. We control for aggregate unobservable difference across year of birth and time-invariant unobservable differences across districts using year of birth fixed effects $\tau_{t}$ and district-specific fixed effects $\delta_{d}$.

There are three main ways in which our estimation differs from that in Duflo (2001). First, while Duflo (2001) uses the Intercensal Survey of Indonesia (SUPAS) 1995 for her analysis, we use the fifth wave of the Indonesian Family Life Survey. We do this because SUPAS does not contain information on time preference. Second, in addition to including the controls used in Duflo (2001) to account for omitted time-varying and region- specific effects correlated with the school construction program, namely the interaction of the year of birth with the population aged 5 to 14 in 1971, the enrollment rate in the district in 1971, and the allocation of the water and sanitation program, the second-largest INPRES program at the time, we include a set of other relevant control variables. These comprise a dummy each for whether the mother and the father of the child had any formal education, a dummy each for whether the individual belongs to the majority ethnicity and the majority religion in Indonesia. We also control for rainfall shocks in early life (in the month of birth and in the first five years after birth) since they have been found to be important determinants of adult health and education (Maccini and Yang (2009)). ${ }^{14}$ Third, while Duflo (2001), interested in the impact of education on wages, uses the sample of males

\footnotetext{
${ }^{14}$ We get the rainfall data from the University of Delaware Center for Climatic Research's "Terrestrial Precipitation: 19002008 Gridded Monthly Time Series (1900-2008) (Version 2.01)". We match the individual-level information to weighted rainfall observations from all latitude-longitude grid points that lie within 200 kilometers of the district center. For a district in any month of any year, the rainfall shock variables is the difference between rainfall in that district in the month of the year and the historical 50 -year district-specific average rainfall in that month. For years after birth, we aggregate this difference over the corresponding twelve months.
} 
only, we use both genders for our analysis. We also cluster our standard errors at the level of the district.

In results consistent with Duflo (2001), we find that exposure to the INPRES school construction program was associated with increase in completed years of formal education. We use predicted education level $\hat{S}_{i d t}$ from the first stage to estimate the second stage effect on the time preference measures by estimating the following equation

$$
2^{s t} \text { stage }: T P_{i d t}=\mu+\beta \hat{S}_{i d t}+\gamma X_{i d t}+\delta_{d}+\tau_{t}+\varepsilon_{i d t}
$$

Here, $T P_{i d t}$ is a measure of impatience for individual $i$ born in district $d$ in year $t$. We use three different measures of time preference. Our first two measures are based on the responses to the timepreference module A and B. For the first (second) measure, the $T P_{i d t}$ variable takes value ' 1 ' if the individuals chooses the present payoff over a future higher reward throughout module A (module B), ' 0 ' otherwise. Since measures based on responses to TP-A and TP-B both capture individual time preference, we need to adjust the standard error estimates for multiple hypothesis testing. For this, we report the p-values from the Romano-Wolf step-down method with our results (Romano and Wolf (2005)). ${ }^{15}$. Another way in which we solve this issue is by constructing a third measure of time preference by combining the information from modules A and B using factor analysis. All the controls from the first stage are included in the second stage.

To facilitate comparison and to check the robustness of our findings, we estimate the relationship between time preference and education specified in equation (2) using an individual fixed-effect specifications. The results are reported in appendix B.

\section{Results and Discussion}

We begin by presenting non-parametric plots describing our instrumental variable approach. In figure 2, we present a non-parametric locally-weighted scatterplot smoothing (LOWESS) plot examining the relationship between the variables of interest. More educated individuals are less likely to be impatient. However, this association does not mean that education makes people more patient. There could be a causal relationship in the opposite direction - more patient individuals attain more schooling. Since the intensity of the school construction under the INPRES program, a supply side policy intervention, that varied at the level of the district affected the educational attainment of the exposed individuals but is unlikely to be associated with the time preference of individuals through other channels, we use it as an instrumental variable for educational attainment of those exposed. Figure 3 suggests that the intensity of

\footnotetext{
${ }^{15}$ The Romano-Wolf method is considered an improvement over the Bonferroni method or Holm's stepdown method (Holm (1979)) and the Westfall and Young method (Westfall et al. (1993))
} 
the school construction program appears to be positively associated with the educational attainment of females exposed to the program. Figure 4 plots the reduced form non-parametric relationship between time preference and the intensity of the school construction program. Districts with a higher number of schools constructed under the program had a lower proportion of impatient individuals suggesting a negative causal effect of education on impatience.

Table 3 reports the results from the instrumental variable method for the sample of females. In the first panel, we present the association (OLS) between the measure of impatience and education for comparison. There appears to be no association between the two variables. We present the results from the IV method in the second panel. Exposure to the INPRES program predicts a higher level of education with a first-stage robust (Kleinbergen-Paap) F-statistic of 11.47. Years of schooling, thus instrumented, is negatively associated with the average level of impatience in the female sample. One more year of schooling decreases the likelihood that an individual will choose the most impatient response to time preference module A and B by 1.2 (statistically not significant) and 9.4 percentage points, respectively. For the composite measure, one more year of schooling reduces the chances of being impatient on the composite measure scale. It is difficult to interpret the magnitude of the coefficient for the composite measure since the outcome is no longer a categorical variable. But signs of the coefficient are consistent across different measures of time preference even though it is not statistically significant for the outcome measure based on responses to time preference module A. Since it has been well established that the instrument satisfies the exclusion restriction (Duflo (2001); Duflo (2004)), the IV coefficients suggest that there is a causal effect of education on time preference - education makes females more patient.

It is important to discuss few caveats here. The estimated coefficients imply that compared to an individual with no schooling, an individual who completed six years of primary school was 7.2 percent less likely to choose the immediate reward throughout time preference module A. Similarly, an individual who completed primary school was 56.4 percent points less likely to choose the immediate reward throughout time preference module B. Compared to the proportion of respondents who choose the immediate reward throughout time preference modules A and B - $68 \%$ and $80 \%$, respectively - the estimated coefficients imply that education does not affect the dimension of time preference captured in responses to time preference module $\mathrm{A}$ as much as it affects the dimension of time preference captured in responses to time preference module B. Moreover, the estimated coefficient for the impact of education on time preference is not statistically significant. It appears that the magnitude of and the delay in future rewards play a role in inter-temporal decision-making. According to Blumenstock et al. (2018), individuals incur a cost in terms of the cognitive resources used up when trying to visualize possible future scenarios. This cost increases with the complexity of the calculations involved and a higher cost results 
in a higher level of present bias. We believe that the cognitive cost of visualizing the scenarios five years in the future (TP-B) is higher than the cost of visualizing a future one year ahead (TP-A). As a result, a higher number of individuals choose the more immediate reward for TP-B. A higher level of education, by increasing the cognition of individuals, may improve their ability to perform the more complex inter-temporal calculation required to visualize a future five year ahead. Subsequently, we find a higher impact of education on time preference B. According to Loewenstein (2000), the long-term trade-offs, like the one in time preference module $\mathrm{B}$, involve a degree of forethought and planning. It is possible that education affects time preference only through improving a person's forethought and planning. But these are mostly speculations. With the limited information available, it is difficult to examine these differences further and we leave it for future research.

Compared to the OLS estimates of the association between education and the time preference measures for the same sample, the IV-2SLS coefficient estimates are much larger in magnitude. ${ }^{16}$ It is possible that the OLS coefficients are smaller because of the potential attenuation bias from measurement error in the years of schooling (Angrist and Krueger (1991)). But even though the sample population completed their education around two decades before the survey, it is, in general, unlikely that the schooling attainments are measured with substantial errors. ${ }^{17}$ The more plausible reason is that the local average treatment effect captured in the IV-2SLS coefficient estimates are larger than the average treatment effect in the sample population captured in the OLS coefficient estimates (Imbens and Angrist (1994); Card (2001)). ${ }^{18}$ Note from figure 2 that the negative association between education and impatience is more significant for grade six and beyond. That is, additional years of schooling do not make a big difference unless you complete primary school. INPRES primary school construction increased the successful completion of primary school and higher enrollment in secondary school. Those who would have completed higher levels of schooling even without the program, might have done so because of their already high rates of patience. Therefore, the magnitudes of the IV estimates, even though large, are not entirely unreasonable. In a sample of females where the average educational attainment was a little more than primary school, it is conceivable that what differentiated patient individuals from impatient ones was the completion of primary school.

In the sample of individuals that we use, exposure to the INPRES program fails to predict differences

\footnotetext{
${ }^{16}$ The estimated coefficients from the individual fixed effect specification are presented in Table B3. The direction of the estimates is consistent with the IV estimates but the coefficients are much smaller and not statistically significant.

${ }^{17}$ For example, Angrist and Krueger (1999) find that the measurement error in self-reported schooling during 1970-2000 for surveys of the United States was around 10-15\%. While it could be higher for a developing country, it is unlikely that measurement error alone can explain the high differences between the OLS and the IV estimates.

${ }^{18}$ Card (2001) surveys 11 studies estimating the labor market returns to schooling and finds a systematically higher IV estimate than the OLS estimate. He proposes that the most plausible explanation for the observation is the difference between the local average treatment effect and the average marginal effect in the population being studied.
} 
in educational attainment for males. As a result, we focus on the sample of females. ${ }^{19}$ Using the 1995 Intercensal Population Survey of Indonesia, Ashraf et al. (2016) find that once the ethnicity of the exposed individuals is controlled for, the impact of the INPRES program was weaker for males but was larger and stronger for females. According to Ashraf et al. (2016), since ethnicity-types in Indonesia differ in their practice of the custom of bride price that depends on the educational attainment of the women, ethnicity is an important control when exploring the impact of the program. Akresh et al. (2018) make use of the 2016 National Socioeconomic Survey of Indonesia to examine the impact of the program on those exposed and their children. They too find a significant impact of the program on the educational attainment of the exposed women. Mazumder et al. (2019), using information from the IFLS, reach the same conclusion. Our findings are also consistent with Maluccio et al. (2009), Maccini and Yang (2009), Field et al. (2009), and Cutler et al. (2010), who find that education policies and exogenous events affecting educational attainment in developing countries have a larger impacts on females.

Even for women, the relatively large magnitudes of the effect, consistent across specifications and definitions of the outcome variable are undermined by the small sample size with large standard errors. Since our estimate captures the long-term effect of education, there is a possibility that some of the effect eroded over time, increasing the variance in time preference. Future research should seek to find stronger identification strategies to examine the effect of education on time preference for all genders. In view of these caveats, we must interpret the results with caution. The results suggest that we cannot deduce no causal effect of education on time preference and future research should further investigate this relationship.

Income and liquidity at the time of the survey could also affect their responses to the time preference questions. For example, as pointed out by Cassidy (2018), individuals who expect to have higher consumption in the future but cannot smooth the consumption into the present because of credit constraints may appear more impatient than those who do not face such constraints. If the liquidity constraints at the time the respondents answered the time preference questions were due to differences in educational attainments caused by exposure to INPRES program, these effects are included in the estimated causal impact of education on time preference. We are unable to distinguish between individuals who appear to present-biased due to liquidity constraints (in the sense of Cassidy (2018)) and those who are actually present-biased. We believe this distinction is not important for our purposes. The variation in the extent of the credit constraints is still caused by variation in education instrumented by exposure to the program and is still reflected in differences in inter-temporal decisions. Therefore, we think of credit constraints due to differences in education as a pathway through which education affects time preference. Any

\footnotetext{
${ }^{19}$ In comparison, Duflo (2001), who focuses on the sample of males only, finds a positive impact of program exposure on education. We discuss how our specification differs from Duflo (2001) and the reasons for making those changes in section ??
} 
residual variation in the liquidity of the respondents at the time of the survey should be orthogonal to education and, therefore, should not bias the estimates.

Next, we examine the robustness of our results to the different definitions of time preference. We present the findings in Table 4. In the first and third columns of the table, we explore the causal effects of education on a female respondent's time preference response category (as described in Section 2.3 and Figure 1) for module A and B, respectively. The second and the fourth column report the impact of education on the imputed time preference value calculated using the method detailed in Section A.1. Consistent with the results in Table 3, more educated respondents are less impatient. The impact is statistically significant for measures that use responses to time preference module B only.

If education affects time preference, this effect should also be visible in individual behavior that is associated with time preference. In Table 5, we report the impact of education on the behavior measures discussed in 2.3. The coefficients are all in the expected direction and are statistically significant for work-for-pay, arisan participation, income and contraception usage by females. While education might affect these behaviors through multiple channels, the results so far suggest that time preference might be one of those channels.

\section{Conclusion}

According to Ramsey's growth model, time discounting is closely related to saving and consumption behavior and it can explain economic growth and inequality (Ramsey (1928)). Despite its far-reaching implications, we do not fully understand the factors affecting time preference. In this study, we try to bridge the gap; we find a significant causal effect of education on time preference as measured by hypothetical survey questions. Our results are robust across different definitions of time preference and different sub-samples from IFLS 4 and 5 survey population. The results, while weak in their statistical significance, underscore the importance of policies aimed at improving educational outcomes. Since improvement in education can make people more patient and, therefore, more likely to invest in human capital further, such policies can trigger a virtuous cycle. They can also give rise to positive health practices like lower chances of taking up smoking and higher use of condoms and productive behavioral responses like higher savings and insurance purchases The results also contribute to the literature on the determinants of non- cognitive abilities that are important inputs into the human capital production function and crucial for overall development of individuals Heckman (2007).

The study points out to avenues for future research. Even though the estimated magnitudes of the effect of education on time preference are sizable and consistent in their direction across measures and specifications, due to the small size of the sample, we cannot always statistically distinguish it from 
zero. Future studies should aim to overcome this shortcoming. Next, we do not have a clear answer to why we observe the association between education and time preference only for time preference elicited using module B and not module $\mathrm{A}$. We believe that the structure of the questions in time preference modules A and B may explain the difference in observed results. We leave a further examination of the reasons behind these differences to future work. Given the limitation of our data and the setting we use, we cannot conclusively identify the pathways through which education affects time preference. We propose a few mechanisms but the evidence we present is suggestive. This presents a rich avenue for future research. Most importantly, we examine just one of the potential determinant of time preference. Future research should attempt to understand other determinants of time preference. It will benefit our understanding of economic behaviors that have an inter-temporal component. 


\section{References}

Akresh, R., Halim, D., and Kleemans, M. (2018). Long-term and intergenerational effects of education: Evidence from school construction in Indonesia. Technical report, National Bureau of Economic Research.

Alan, S. and Ertac, S. (2018). Fostering patience in the classroom: Results from randomized educational intervention. Journal of Political Economy, 126(5):1865-1911.

Anderson, C. L., Dietz, M., Gordon, A., and Klawitter, M. (2004). Discount rates in Vietnam. Economic Development and Cultural Change, 52(4):873-887.

Angrist, J. D. and Krueger, A. B. (1991). Does compulsory school attendance affect schooling and earnings? The Quarterly Journal of Economics, 106(4):979-1014.

Angrist, J. D. and Krueger, A. B. (1999). Empirical strategies in labor economics. Handbook of labor economics, 3:1277-1366.

Ardener, S. (1964). The comparative study of rotating credit associations. The Journal of the Royal Anthropological Institute of Great Britain and Ireland, 94(2):201-229.

Ashraf, N., Bau, N., Nunn, N., and Voena, A. (2016). Bride price and female education. Technical report, National Bureau of Economic Research.

Barsky, R. B., Juster, F. T., Kimball, M. S., and Shapiro, M. D. (1997). Preference parameters and behavioral heterogeneity: An experimental approach in the health and retirement study. The Quarterly Journal of Economics, 112(2):pp. 537-579.

Bauer, M. and Chytilová, J. (2010). The impact of education on subjective discount rate in Ugandan villages. Economic Development and Cultural Change, 58(4):643-669.

Becker, G. S. and Mulligan, C. B. (1997). The endogenous determination of time preference. The Quarterly Journal of Economics, pages 729-758.

Ben Halima, B. and Ben Halima, M. A. (2009). Time preferences and job search: Evidence from France. Labour, 23(3):535-558.

Benjamin, D. J., Brown, S. A., and Shapiro, J. M. (2013). Who is 'behavioral'? Cognitive ability and anomalous preferences. Journal of the European Economic Association, 11(6):1231-1255.

Benjamin, D. J., Choi, J. J., and Fisher, G. (2016). Religious identity and economic behavior. Review of Economics and Statistics, 98(4):617-637.

Benjamin, D. J., Choi, J. J., Strickland, A. J., et al. (2010). Social identity and preferences. The American Economic Review, 100(4):1913-1928.

Bennett, D., Naqvi, A., and Schmidt, W.-P. (2018). Learning, hygiene and traditional medicine. The Economic Journal, 128(612):F545-F574.

Bickel, W. K., Odum, A. L., and Madden, G. J. (1999). Impulsivity and cigarette smoking: Delay discounting in current, never, and ex-smokers. Psychopharmacology, 146(4):447-454.

Black, S. E., Devereux, P. J., and Salvanes, K. G. (2011). Too young to leave the nest? The effects of school starting age. The Review of Economics and Statistics, 93(2):455-467.

Blumenstock, J., Callen, M., and Ghani, T. (2018). Why do defaults affect behavior? Experimental evidence from Afghanistan. The American Economic Review, 108(10):2868-2901. 
Bouman, F. J. (1977). Indigenous savings and credit societies in the third world. a message/unenseignement: Les societes indigenes dépargne et de credit. Savings and development, pages $181-219$.

Brown, R., Montalva, V., Thomas, D., and Velásquez, A. (2017). Impact of violent crime on risk aversion: Evidence from the Mexican drug war. Technical report, National Bureau of Economic Research.

Callen, M. (2015). Catastrophes and time preference: Evidence from the Indian ocean earthquake. Journal of Economic Behavior \& Organization, 118:199-214.

Callen, M., Isaqzadeh, M., Long, J. D., and Sprenger, C. (2014). Violence and risk preference: Experimental evidence from Afghanistan. The American Economic Review, 104(1):123-148.

Cameron, L. and Shah, M. (2015). Risk-taking behavior in the wake of natural disasters. Journal of Human Resources, 50(2):484-515.

Card, D. (2001). Estimating the return to schooling: Progress on some persistent econometric problems. Econometrica, 69(5):1127-1160.

Carlsson, M., Dahl, G. B., Öckert, B., and Rooth, D.-O. (2015). The effect of schooling on cognitive skills. Review of Economics and Statistics, 97(3):533-547.

Cassar, A., Healy, A., and Von Kessler, C. (2011). Trust, risk, and time preferences after a natural disaster: Experimental evidence from Thailand. Unpublished manuscript.

Cassidy, R. (2018). Are the poor really so present-biased? Experimental evidence from Pakistan. Technical report, Working paper.

Ceci, S. J. and Williams, W. M. (1997). Schooling, intelligence, and income. American Psychologist, 52(10): 1051.

Chen, M. K. (2013). The effect of language on economic behavior: Evidence from savings rates, health behaviors, and retirement assets. The American Economic Review, 103(2):690-731.

Coller, M. and Williams, M. B. (1999). Eliciting individual discount rates. Experimental Economics, 2(2):107-127.

Cutler, D., Fung, W., Kremer, M., Singhal, M., and Vogl, T. (2010). Early-life malaria exposure and adult outcomes: Evidence from malaria eradication in India. American Economic Journal: Applied Economics, 2(2):72-94.

de Wit, H., Flory, J. D., Acheson, A., McCloskey, M., and Manuck, S. B. (2007). Iq and nonplanning impulsivity are independently associated with delay discounting in middle-aged adults. Personality and Individual Differences, 42(1):111-121.

DellaVigna, S. and Paserman, M. D. (2005). Job search and impatience. Journal of Labor Economics, 23(3):527-588.

Dohmen, T., Enke, B., Falk, A., Huffman, D., Sunde, U., et al. (2015). Patience and the wealth of nations. Technical report, Working Paper.

Dohmen, T., Falk, A., Huffman, D., and Sunde, U. (2010). Are risk aversion and impatience related to cognitive ability? The American Economic Review, 100(3):pp. 1238-1260.

Dohmen, T., Huffman, D., Schupp, J., Falk, A., Sunde, U., and Wagner, G. G. (2011). Individual risk attitudes: Measurement, determinants, and behavioral consequences. Journal of the European Economic Association, 9(3):pp. 522-550. 
Duflo, E. (2001). Schooling and labor market consequences of school construction in Indonesia: Evidence from an unusual policy experiment. The American Economic Review, 91(4):pp. 795-813.

Duflo, E. (2004). The medium run effects of educational expansion: Evidence from a large school construction program in Indonesia. Journal of Development Economics, 74(1):163-197.

Duncan, J. and Owen, A. M. (2000). Common regions of the human frontal lobe recruited by diverse cognitive demands. Trends in Neurosciences, 23(10):475-483.

Falch, T. and Sandgren Massih, S. (2011). The effect of education on cognitive ability. Economic Inquiry, 49(3):838-856.

Falk, A., Becker, A., Dohmen, T., Enke, B., Huffman, D., and Sunde, U. (2018). Global evidence on economic preferences. The Quarterly Journal of Economics, 133(4):1645-1692.

Field, E., Robles, O., and Torero, M. (2009). Iodine deficiency and schooling attainment in Tanzania. American Economic Journal: Applied Economics, pages 140-169.

Frederick, S., Loewenstein, G., and O'donoghue, T. (2002). Time discounting and time preference: A critical review. Journal of Economic Literature, pages 351-401.

Fuchs, V. R. (1982). Time preference and health: An exploratory study. In Economic Aspects of Health, pages 93-120. University of Chicago Press.

Golsteyn, B. H., Grönqvist, H., and Lindahl, L. (2014). Adolescent time preferences predict lifetime outcomes. The Economic Journal, 124(580).

Green, D. A. and Riddell, W. C. (2012). Understanding educational impacts: The role of literacy and numeracy skills. 11th IZA/SOLE Transatlantic Meeting of Labor Economist. Buch/Ammersee, Germany. Retrieved from http://www. iza. org/conference_files/TAM2012/riddell_w5670. pdf.

Grossman, M. (2006). Education and nonmarket outcomes. Handbook of the Economics of Education, $1: 577-633$.

Guiso, L., Sapienza, P., and Zingales, L. (2013). Time varying risk aversion. Technical report, National Bureau of Economic Research.

Hamoudi, A. (2006). Risk preferences in households and families. Unpublished Manuscript.

Heckman, J., Pinto, R., and Savelyev, P. (2013). Understanding the mechanisms through which an influential early childhood program boosted adult outcomes. The American Economic Review, 103(6):2052-2086.

Heckman, J. J. (2007). The economics, technology, and neuroscience of human capability formation. Proceedings of the National Academy of Sciences, 104(33):13250-13255.

H'Madoun, M. and Nonneman, W. (2012). Time preference, immigrant background and religion.

Holm, S. (1979). A simple sequentially rejective multiple test procedure. Scandinavian Journal of Statistics, pages 65-70.

Huber, M. (2014). Identifying causal mechanisms (primarily) based on inverse probability weighting. Journal of Applied Econometrics, 29(6):920-943.

Ida, T. and Goto, R. (2009). Simultaneous measurement of time and risk preferences: Stated preference discrete choice modeling analysis depending on smoking behavior. International Economic Review, 50(4):1169-1182.

Imai, K., Keele, L., and Tingley, D. (2010a). A general approach to causal mediation analysis. Psychological methods, 15(4):309. 
Imai, K., Keele, L., Yamamoto, T., et al. (2010b). Identification, inference and sensitivity analysis for causal mediation effects. Statistical Science, 25(1):51-71.

Imbens, G. and Angrist, J. (1994). Identification and estimation of local average treatment effects. Econometrica, 62(2):467-475.

Jensen, R. and Lleras-Muney, A. (2012). Does staying in school (and not working) prevent teen smoking and drinking? Journal of Health Economics, 31(4):644-657.

Johnson, M. W. and Bickel, W. K. (2002). Within-subject comparison of real and hypothetical money rewards in delay discounting. Journal of the Experimental Analysis of Behavior, 77(2):129-146.

Kahneman, D. and Tversky, A. (1981). The simulation heuristic. Technical report, DTIC Document.

Kang, M.-I. and Ikeda, S. (2014). Time discounting and smoking behavior: Evidence from a panel survey. Health Economics, 23(12):1443-1464.

Kaplan, J. T., Gimbel, S. I., and Harris, S. (2016). Neural correlates of maintaining one's political beliefs in the face of counterevidence. Scientific Reports, 6:39589.

Khwaja, A., Silverman, D., and Sloan, F. (2007). Time preference, time discounting, and smoking decisions. Journal of Health Economics, 26(5):927-949.

Kirby, K. N., Godoy, R., Reyes-Garcia, V., Byron, E., Apaza, L., Leonard, W., Perez, E., Vadez, V., and Wilkie, D. (2002). Correlates of delay-discount rates: Evidence from Tsimane'Amerindians of the Bolivian rain forest. Journal of Economic Psychology, 23(3):291-316.

Knoch, D. and Fehr, E. (2007). Resisting the power of temptations. Annals of the New York Academy of Sciences, 1104(1):123-134.

Kühberger, A., Schulte-Mecklenbeck, M., and Perner, J. (2002). Framing decisions: Hypothetical and real. Organizational Behavior and Human Decision Processes, 89(2):1162-1175.

Lawrance, E. C. (1991a). Poverty and the rate of time preference: Evidence from panel data. Journal of Political economy, 99(1):54-77.

Lawrance, E. C. (1991b). Poverty and the rate of time preference: Evidence from panel data. Journal of Political economy, 99(1):54-77.

Leigh, J. P. (1986). Accounting for tastes: Correlates of risk and time preferences. Journal of Post Keynesian Economics, 9(1):pp. 17-31.

Lichand, G. and Mani, A. (2016). Cognitive droughts. Competitive Advantage in the Global Economy, 485:486.

Loewenstein, G. (2000). Emotions in economic theory and economic behavior. The American Economic Review, 90(2):426-432.

Maccini, S. and Yang, D. (2009). Under the weather: Health, schooling, and economic consequences of early-life rainfall. The American Economic Review, 99(3):pp. 1006-1026.

MacKinnon, D. P., Lockwood, C. M., Brown, C. H., Wang, W., and Hoffman, J. M. (2007). The intermediate endpoint effect in logistic and probit regression. Clinical Trials, 4(5):499-513.

Madden, G. J., Begotka, A. M., Raiff, B. R., and Kastern, L. L. (2003). Delay discounting of real and hypothetical rewards. Experimental and clinical psychopharmacology, 11(2):139.

Maluccio, J. A., Hoddinott, J., Behrman, J. R., Martorell, R., Quisumbing, A. R., and Stein, A. D. (2009). The impact of improving nutrition during early childhood on education among Guatemalan adults. The Economic Journal, 119(537):734-763. 
Mani, A., Mullainathan, S., Shafir, E., and Zhao, J. (2013). Poverty impedes cognitive function. Science, 341(6149):976-980.

Mazumder, B., Rosales-Rueda, M., and Triyana, M. (2019). Intergenerational human capital spillovers: Indonesia's school construction and its effects on the next generation. AEA Papers and Proceedings, 109:243-49.

Meier, S. and Sprenger, C. D. (2015). Temporal stability of time preferences. Review of Economics and Statistics, 97(2):273-286.

Miller, B. L. and Cummings, J. L. (2017). The human frontal lobes: Functions and disorders. Guilford Publications.

$\mathrm{Ng}$, J. (2013). Elicited risk and time preferences: The role of demographics, cognition, and interviewers. University of Southern California Job Market Paper.

Non, A. and Tempelaar, D. (2016). Time preferences, study effort, and academic performance. Economics of Education Review, 54:36-61.

Oreopoulos, P. and Salvanes, K. G. (2011). Priceless: The non-pecuniary benefits of schooling. The Journal of Economic Perspectives, pages 159-184.

Pender, J. L. (1996). Discount rates and credit markets: Theory and evidence from rural India. Journal of Development Economics, 50(2):257-296.

Perez-Arce, F. (2017). The effect of education on time preferences. Economics of Education Review, 56:52-64.

Pitt, M. M., Rosenzweig, M. R., and Hassan, M. N. (2012). Human capital investment and the gender division of labor in a brawn-based economy. The American Economic Review, 102(7):3531-3560.

Ramsey, F. P. (1928). A mathematical theory of saving. The Economic Journal, 38(152):543-559.

Read, D., Loewenstein, G., Rabin, M., Keren, G., and Laibson, D. (1999). Choice bracketing. In Elicitation of Preferences, pages 171-202. Springer.

Romano, J. P. and Wolf, M. (2005). Stepwise multiple testing as formalized data snooping. Econometrica, 73(4):1237-1282.

Rubalcava, L., Teruel, G., and Thomas, D. (2009). Investments, time preferences, and public transfers paid to women. Economic Development and Cultural Change, 57(3):507-538.

Rzezak, P., Squarzoni, P., Duran, F. L., Alves, T. d. T. F., Tamashiro-Duran, J., Bottino, C. M., Ribeiz, S., Lotufo, P. A., Menezes, P. R., Scazufca, M., et al. (2015). Relationship between brain age-related reduction in gray matter and educational attainment. PloS One, 10(10):e0140945.

Shapiro, J. M. (2005). Is there a daily discount rate? Evidence from the food stamp nutrition cycle. Journal of Public Economics, 89(2):303-325.

Stigler, G. J. and Becker, G. S. (1977). De gustibus non est disputandum. The American Economic Review, pages 76-90.

Strauss, J., Witoelar, F., and Sikoki, B. (2016). The fifth wave of the Indonesia family life survey: Overview and field report.

Sutter, M., Kocher, M. G., Glätzle-Rützler, D., and Trautmann, S. T. (2013). Impatience and uncertainty: Experimental decisions predict adolescents' field behavior. The American Economic Review, 103(1):510-531. 
Tanaka, T., Camerer, C. F., and Nguyen, Q. (2010). Risk and time preferences: Linking experimental and household survey data from Vietnam. The American Economic Review, 100(1):557.

Voors, M. J., Nillesen, E. E., Verwimp, P., Bulte, E. H., Lensink, R., and Van Soest, D. P. (2012). Violent conflict and behavior: A field experiment in Burundi. The American Economic Review, 102(2):941964.

Westfall, P. H., Young, S. S., et al. (1993). Resampling-based multiple testing: Examples and methods for p-value adjustment, volume 279. John Wiley \& Sons. 
Figure 1: TIME PREFERENCE QUESTIONNAIRES

(a) TIME PREFERENCE MODULE A

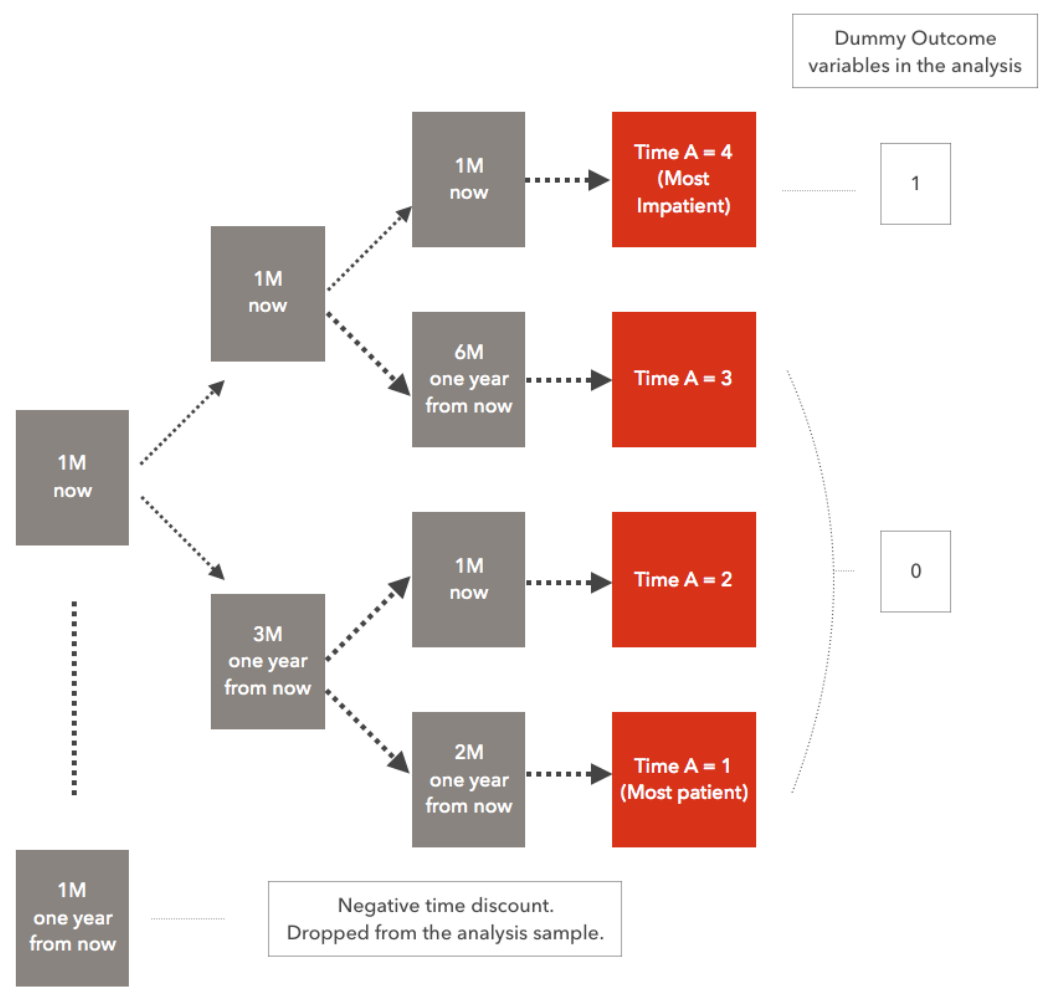

(b) TIME PREFERENCE MODULE B

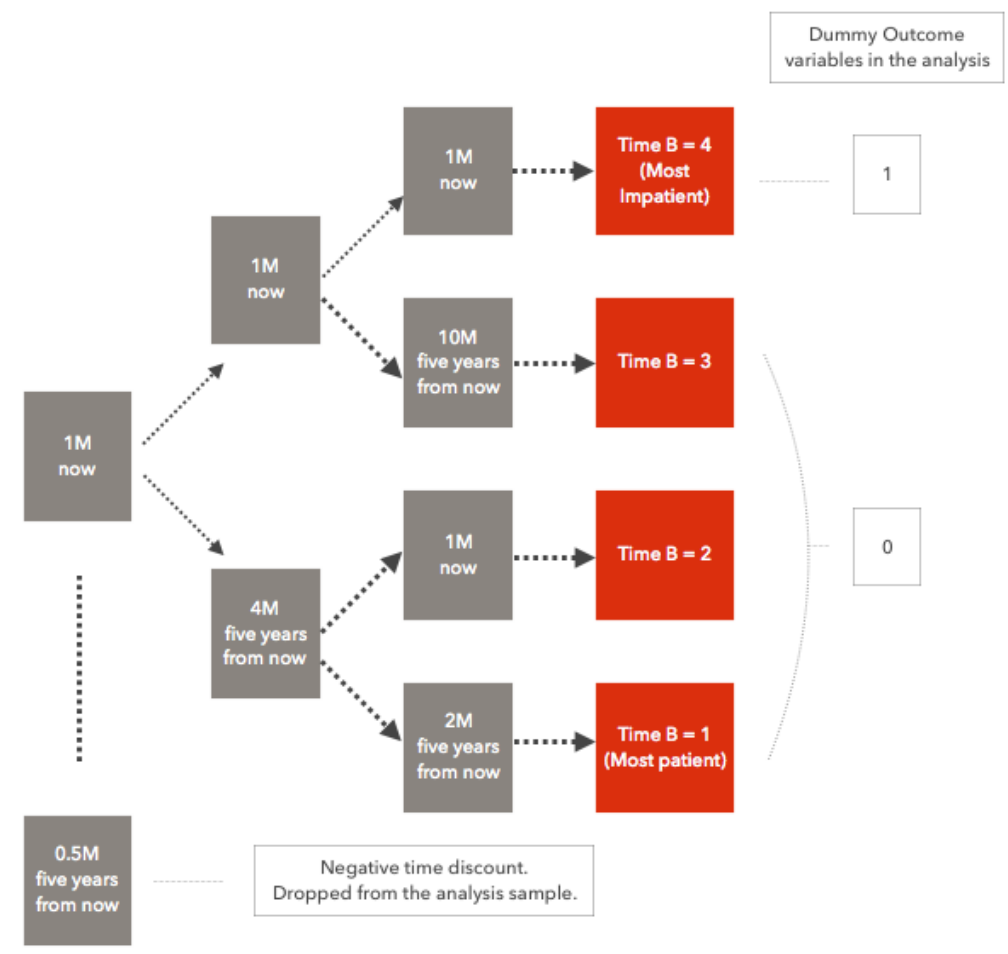


Figure 2: THE CORRELATION BETWEEN TIME PREFERENCE AND EDUCATION

(a) TIME PREFERENCE A

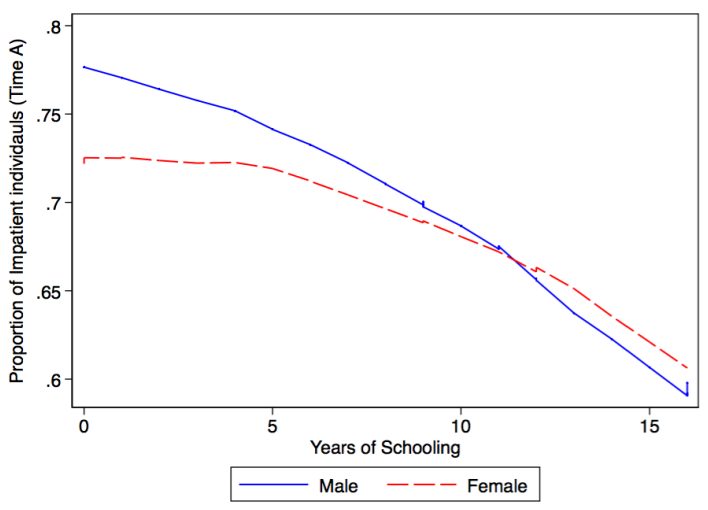

(b) TIME PREFERENCE B

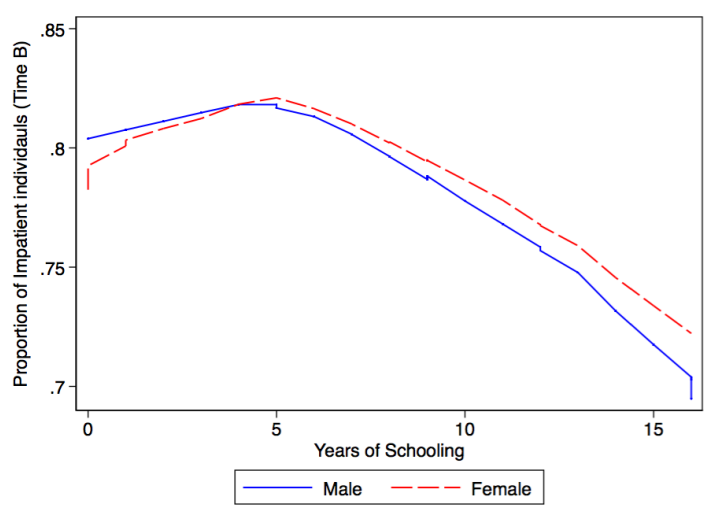

NOTE: The figures use the entire IFLS sample of males and females who respond to the time preference questions except those who choose negative discount factor.

Figure 3: YEARS OF EDUCATION (RESIDUAL) BY EXPOSURE STATUS
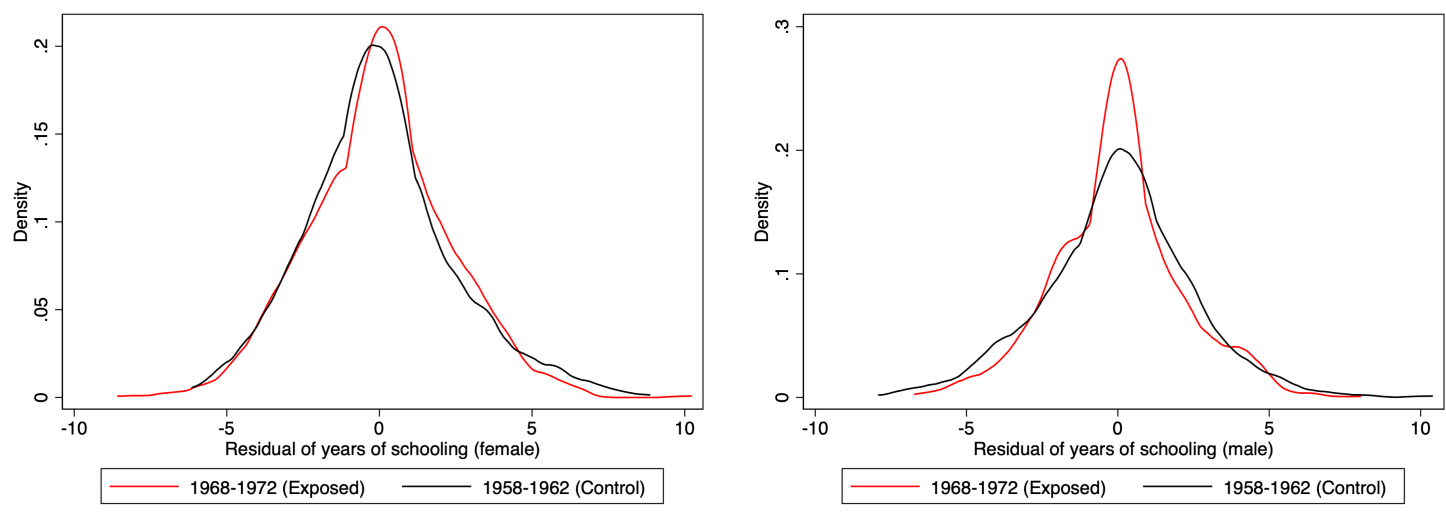

NOTE: The figure plots the distribution of the residual obtained from the regression of years of education on all controls included in the main IV specification except the interaction of exposure status and Inpres intensity.

Figure 4: INTENSITY OF THE INPRES PROGRAM AND TIME PREFERENCE (TP-B) OF FEMALES

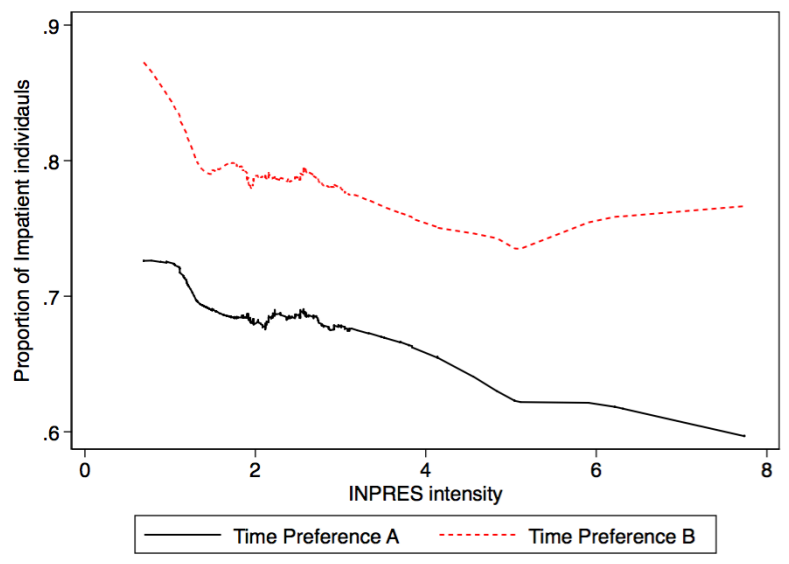


Table 1: SUMMARY STATISTICS

\begin{tabular}{|c|c|c|c|c|c|c|}
\hline \multirow{3}{*}{ Time Preference A } & \multicolumn{2}{|c|}{ POOLED $(\mathrm{N}=3,005)$} & \multicolumn{2}{|c|}{$\operatorname{MALE}(\mathrm{N}=1,541)$} & \multicolumn{2}{|c|}{ FEMALE $(\mathrm{N}=1,464)$} \\
\hline & \multicolumn{6}{|c|}{ PERCENTAGE RESPONDENTS } \\
\hline & & & & & & \\
\hline 1 ( = Most patient) & 0.083 & & 0.081 & & 0.084 & \\
\hline 2 & 0.075 & & 0.080 & & 0.070 & \\
\hline 3 & 0.163 & & 0.164 & & 0.162 & \\
\hline 4 ( = Most Impatient) & 0.679 & & 0.675 & & 0.684 & \\
\hline \multicolumn{7}{|l|}{ Time Preference B } \\
\hline 1 ( = Most patient) & 0.015 & & 0.014 & & 0.016 & \\
\hline 2 & 0.044 & & 0.039 & & 0.049 & \\
\hline 3 & 0.151 & & 0.163 & & 0.139 & \\
\hline \multirow[t]{3}{*}{4 ( = Most Impatient) } & 0.790 & & 0.785 & & 0.796 & \\
\hline & \multicolumn{6}{|c|}{ DEMOGRAPHICS } \\
\hline & MEAN & S.D. & MEAN & S.D. & MEAN & S.D. \\
\hline Age & 46.61 & 5.473 & 46.27 & 5.532 & 46.97 & 5.389 \\
\hline Years of schooling & 9.011 & 4.240 & 9.409 & 4.173 & 8.592 & 4.271 \\
\hline Mother has no education & 0.353 & 0.478 & 0.368 & 0.482 & 0.337 & 0.473 \\
\hline Father has no education & 0.216 & 0.412 & 0.224 & 0.417 & 0.208 & 0.406 \\
\hline
\end{tabular}

NOTE: The sample consists of cohorts born between 1958 to 1962 (control cohorts) and 1968 to 1972 (exposed cohorts). 
Table 2: ASSOCIATION BETWEEN TIME PREFERENCE AND BEHAVIOR

\begin{tabular}{|c|c|c|c|c|c|c|c|c|}
\hline & SMOKING & $\begin{array}{l}\text { WORK } \\
\text { FOR PAY }\end{array}$ & $\begin{array}{c}\text { ANY } \\
\text { SAVING }\end{array}$ & $\begin{array}{l}\text { AMOUNT } \\
\text { SAVED }\end{array}$ & $\begin{array}{c}\text { ARISAN } \\
\text { PARTICIPATION }\end{array}$ & $\begin{array}{l}\text { PARTICIPATED IN } \\
\text { SAVINGS GROUP }\end{array}$ & $\begin{array}{c}\text { LOG OF } \\
\text { TOTAL INCOME }\end{array}$ & CONTRACEPTION \\
\hline & \multicolumn{8}{|c|}{ TIME PREFERENCE A } \\
\hline \multirow[t]{2}{*}{ Female } & -0.002 & $-0.031 * * *$ & $-0.041 * * *$ & $-0.620 * * *$ & $-0.024 * *$ & -0.003 & $-0.234 *$ & $-0.059 * * *$ \\
\hline & $(0.003)$ & $(0.011)$ & $(0.012)$ & $(0.162)$ & $(0.010)$ & $(0.004)$ & $(0.140)$ & $(0.021)$ \\
\hline \multirow[t]{2}{*}{ Male } & $0.029 * * *$ & 0.041 & $-0.059 * *$ & $-0.965 * * *$ & $-0.034 * * *$ & -0.003 & -0.145 & \\
\hline & $(0.010)$ & $(0.029)$ & $(0.023)$ & $(0.333)$ & $(0.008)$ & $(0.004)$ & $(0.104)$ & \\
\hline \multirow[t]{3}{*}{ Pooled } & 0.010 & $-0.019 *$ & $-0.044 * * *$ & $-0.682 * * *$ & $-0.028 * * *$ & -0.003 & $-0.240 * *$ & \\
\hline & $(0.007)$ & $(0.011)$ & $(0.010)$ & $(0.145)$ & $(0.007)$ & $(0.004)$ & $(0.100)$ & \\
\hline & \multicolumn{8}{|c|}{ TIME PREFERENCE B } \\
\hline \multirow[t]{2}{*}{ Female } & -0.005 & $-0.022 *$ & $-0.034 * * *$ & $-0.591 * * *$ & -0.018 & 0.002 & $-0.284 *$ & -0.029 \\
\hline & $(0.003)$ & $(0.013)$ & $(0.013)$ & $(0.182)$ & $(0.011)$ & $(0.004)$ & $(0.160)$ & $(0.023)$ \\
\hline \multirow[t]{2}{*}{ Male } & $0.020^{*}$ & -0.010 & $-0.057 * *$ & $-1.043 * * *$ & $-0.021 * *$ & $-0.011^{* *}$ & $-0.249 * *$ & \\
\hline & $(0.012)$ & $(0.033)$ & $(0.027)$ & $(0.381)$ & $(0.009)$ & $(0.005)$ & $(0.116)$ & \\
\hline \multirow[t]{3}{*}{ Pooled } & -0.013 & -0.014 & $-0.036 * * *$ & $-0.615 * * *$ & -0.013 & -0.005 & $-0.425 * * *$ & \\
\hline & $(0.008)$ & $(0.012)$ & $(0.012)$ & $(0.163)$ & $(0.008)$ & $(0.003)$ & $(0.113)$ & \\
\hline & \multicolumn{8}{|c|}{ COMPOSITE MEASURE } \\
\hline \multirow[t]{2}{*}{ Female } & $-0.002 *$ & $-0.014 * * *$ & $-0.011 * *$ & $-0.185^{* * *}$ & -0.004 & -0.001 & -0.082 & -0.013 \\
\hline & $(0.001)$ & $(0.005)$ & $(0.005)$ & $(0.064)$ & $(0.004)$ & $(0.002)$ & $(0.056)$ & $(0.008)$ \\
\hline \multirow[t]{2}{*}{ Male } & $0.007 *$ & -0.003 & $-0.018 * *$ & $-0.370 * * *$ & $-0.009 * * *$ & $-0.005 * * *$ & $-0.083^{*} *$ & \\
\hline & $(0.004)$ & $(0.012)$ & $(0.009)$ & $(0.128)$ & $(0.003)$ & $(0.002)$ & $(0.041)$ & \\
\hline \multirow[t]{2}{*}{ Pooled } & 0.001 & $-0.010 * *$ & $-0.012 * * *$ & $-0.197 * * *$ & $-0.006 * *$ & $-0.003 * * *$ & $-0.108 * * *$ & \\
\hline & $(0.003)$ & $(0.004)$ & $(0.004)$ & $(0.057)$ & $(0.003)$ & $(0.001)$ & $(0.040)$ & \\
\hline Observations (Female) & 10,392 & 5,836 & 6,948 & 6,678 & 10,392 & 9,006 & 10,185 & 8,832 \\
\hline Observations (Male) & 8,356 & 710 & 1,672 & 1,606 & 8,356 & 7,280 & 8,340 & \\
\hline Observations (Pooled) & 18,748 & 6,546 & 8,620 & 8,284 & 18,748 & 16,286 & 18,525 & \\
\hline
\end{tabular}

NOTE: $* p<0.1, * * p<0.05, * * * p<0.01$. Higher values of the dependent variables denote higher levels of impatience. Robust standard errors are clustered at the province level. We include controls for parental education, ethnicity, religion, birth month-year FE, district of birth $\mathrm{FE}$, current district of residence FE, language used for the interview, an indicator of the order in which the respondent answered the time preference modules, rainfall in the in-utero and early-life period. 
Table 3: IMPACT OF EDUCATION ON TIME PREFERENCE OF FEMALES

TIME PREFERENCE A TIME PREFERENCE B COMPOSITE MEASURE

(1)

(2)

(3)

\begin{tabular}{lccc}
\hline \multirow{2}{*}{ Years of schooling } & \multicolumn{3}{c}{ ORDINARY LEAST SQUARES (OLS) MODEL } \\
\cline { 2 - 4 } & -0.000 & -0.000 & 0.011 \\
R-squared & $(0.004)$ & $(0.003)$ & $(0.009)$ \\
\hline \multirow{2}{*}{ Years of schooling } & 0.120 & 0.115 & 0.108 \\
\cline { 2 - 4 } & \multicolumn{2}{c}{ INSTRUMENTAL VARIABLE (IV) MODEL } \\
RF Step-down P-values & -0.012 & $-0.094^{* * *}$ & $-0.196^{*}$ \\
IV First stage F & $(0.045)$ & $(0.034)$ & $(0.117)$ \\
\hline Observations & 0.867 & 0.056 & \\
Mean DV & 11.47 & 11.47 & 11.47 \\
Mean Years of schooling & 1,464 & 1,464 & -0.007 \\
\hline
\end{tabular}

NOTE: $* p<0.1, * * p<0.05, * * * p<0.01$. Higher values of the dependent variables denote higher levels of impatience. RF Step-down p-values are Romano-Wolf's step down adjusted p-values. Robust standard errors are clustered at the province level. The sample consists of INPRES-exposed cohorts born between 1968 and 1972 and control cohorts born between 1958 and 1962. Following Duflo (2001), we control for the 1971 children's population, the 1971 primary school enrollment rate, and the 1971 water and sanitation program exposure status of the district that the individual was born in. We also include controls for parental education, ethnicity, religion, birth month-year FE, district of birth FE, current district of residence FE, language used for the interview, an indicator of the order in which the respondent answered the time preference modules, rainfall in the in-utero and early-life period. 
Table 4: IMPACT OF EDUCATION ON CATEGORIES AND IMPUTED TIME PREFERENCE VALUE OF FEMALES

\begin{tabular}{lcccc}
\hline & CATEGORY TP-A & IMPUTED TP-A & CATEGORY TP-B & IMPUTED TP-B \\
\hline Years of schooling & -0.068 & -0.163 & $-0.129^{* *}$ & $-0.169^{* * *}$ \\
& $(0.106)$ & $(0.432)$ & $(0.059)$ & $(0.062)$ \\
Mean of DV & & & & \\
Mean of YoS & 3.445 & 9.216 & 3.714 & 2.799 \\
IV F-stat & 8.592 & 8.592 & 8.592 & 8.592 \\
\hline
\end{tabular}

NOTE: $* p<0.1, * * p<0.05, * * * p<0.01$. Higher values of the dependent variables denote higher levels of impatience. A respondent's time preference category is constructed as per Figure 1. The imputed value of time preference is calculated using the method detailed in A.1. Robust standard errors are clustered at the province level. The specification and all controls are the same as those used in Table 3 .

Table 5: IMPACT OF EDUCATION ON FEMALE BEHAVIOR

\begin{tabular}{|c|c|c|c|c|c|c|c|c|}
\hline & SMOKING & $\begin{array}{l}\text { WORK } \\
\text { FOR PAY }\end{array}$ & $\begin{array}{c}\text { ANY } \\
\text { SAVING }\end{array}$ & $\begin{array}{l}\text { AMOUNT } \\
\text { SAVED }\end{array}$ & $\begin{array}{c}\text { ARISAN } \\
\text { PARTICIPATION }\end{array}$ & $\begin{array}{l}\text { PARTICIPATED IN } \\
\text { SAVINGS GROUP }\end{array}$ & $\begin{array}{c}\text { LOG OF } \\
\text { TOTAL INCOME }\end{array}$ & CONTRACEPTION \\
\hline Years of schooling & $\begin{array}{l}0.016 \\
(0.025)\end{array}$ & $\begin{array}{l}0.103 * * * \\
(0.036)\end{array}$ & $\begin{array}{l}0.035 \\
(0.027)\end{array}$ & $\begin{array}{c}0.051 \\
(0.068)\end{array}$ & $\begin{array}{l}0.101^{*} \\
(0.061)\end{array}$ & $\begin{array}{l}-0.012 \\
(0.021)\end{array}$ & $\begin{array}{c}1.838 * * * \\
(0.704)\end{array}$ & $\begin{array}{l}0.155^{* *} \\
(0.071)\end{array}$ \\
\hline RF Step-down P-values & 0.72 & 0.00 & 0.33 & 0.72 & 0.19 & 0.72 & 0 & 0.09 \\
\hline IV F-stat & 6.99 & 11.47 & 11.47 & 11.47 & 11.47 & 8.456 & 11.09 & 9.107 \\
\hline Observations & 1,301 & 1,464 & 1,464 & 1,464 & 1,464 & 1,269 & 1,432 & 952 \\
\hline
\end{tabular}

NOTE: $* p<0.1, * * p<0.05, * * * p<0.01$. Robust standard errors are clustered at the province level. RF Step-down p-values are Romano-Wolf's step down adjusted p-values. The specification and all controls are the same as those used in Table 3. 


\section{A Appendix}

Table A1: THE EFFECT OF EDUCATION ON NEGATIVE TIME DISCOUNTING

\begin{tabular}{|c|c|c|c|c|c|c|}
\hline \multirow[b]{3}{*}{ Years of schooling } & \multicolumn{6}{|c|}{ NEGATIVE TIME DISCOUNT FACTOR FOR MODULE } \\
\hline & \multicolumn{3}{|c|}{ TP-A } & \multicolumn{3}{|c|}{ TP-B } \\
\hline & $\begin{array}{c}-0.100 * * \\
(0.047)\end{array}$ & $\begin{array}{c}0.202 \\
(0.526)\end{array}$ & $\begin{array}{l}-0.020 \\
(0.017)\end{array}$ & $\begin{array}{l}-0.014 \\
(0.034)\end{array}$ & $\begin{array}{l}-0.227 \\
(0.603)\end{array}$ & $\begin{array}{l}-0.014 \\
(0.014)\end{array}$ \\
\hline Observations & 3,130 & 1,558 & 1,572 & 3,130 & 1,558 & 1,572 \\
\hline Sample & Pooled & Male & Female & Pooled & Male & Female \\
\hline Mean of DV & 0.030 & 0.033 & 0.027 & 0.027 & 0.033 & 0.022 \\
\hline Mean of YoS & 8.411 & 8.904 & 7.922 & 8.411 & 8.904 & 7.922 \\
\hline IV F-stat & 2.284 & 0.0961 & 8.061 & 2.284 & 0.0961 & 8.061 \\
\hline
\end{tabular}

NOTE: $* p<0.1$, ** $p<0.05, * * * p<0.01$. Negative Time Discount factor is a dummy variable that takes value ' 1 ' if the respondent preferred an equal or lower reward in the future to an reward today, ' 0 ' otherwise. Robust standard errors are clustered at the province level. The specification and all controls are the same as those used in Table 3.

Table A2: CORRELATION BETWEEN TP-A AND TP-B

\begin{tabular}{lcccccc}
\hline & \multicolumn{3}{c}{ FULL IFLS SAMPLE } & \multicolumn{3}{c}{ IV SAMPLE } \\
& $(1)$ & $(2)$ & $(3)$ & $(4)$ & $(5)$ & $(6)$ \\
\hline Correlation coefficient & $0.858^{* * *}$ & $0.847^{* * *}$ & $0.866^{* * *}$ & $0.813^{* * * *}$ & $0.826 * * *$ & $0.796^{* * *}$ \\
& $(0.021)$ & $(0.028)$ & $(0.024)$ & $(0.035)$ & $(0.038)$ & $(0.041)$ \\
& & & & & & \\
& Pooled & Male & Female & Pooled & Male & Female \\
Observations & 36,852 & 16,378 & 20,474 & 3,005 & 1,541 & 1,464 \\
R-squared & 0.361 & 0.404 & 0.368 & 0.333 & 0.383 & 0.366 \\
\hline
\end{tabular}

NOTE: $* p<0.1$, ** $p<0.05, * * * p<0.01$. A respondent's time preference category is constructed as per Figure 1. The coefficients reported measure the correlation between a respondent's categories across time preference modules for different samples. 
Table A3: ASSOCIATION BETWEEN TIME PREFERENCE CATEGORY AND BEHAVIOR

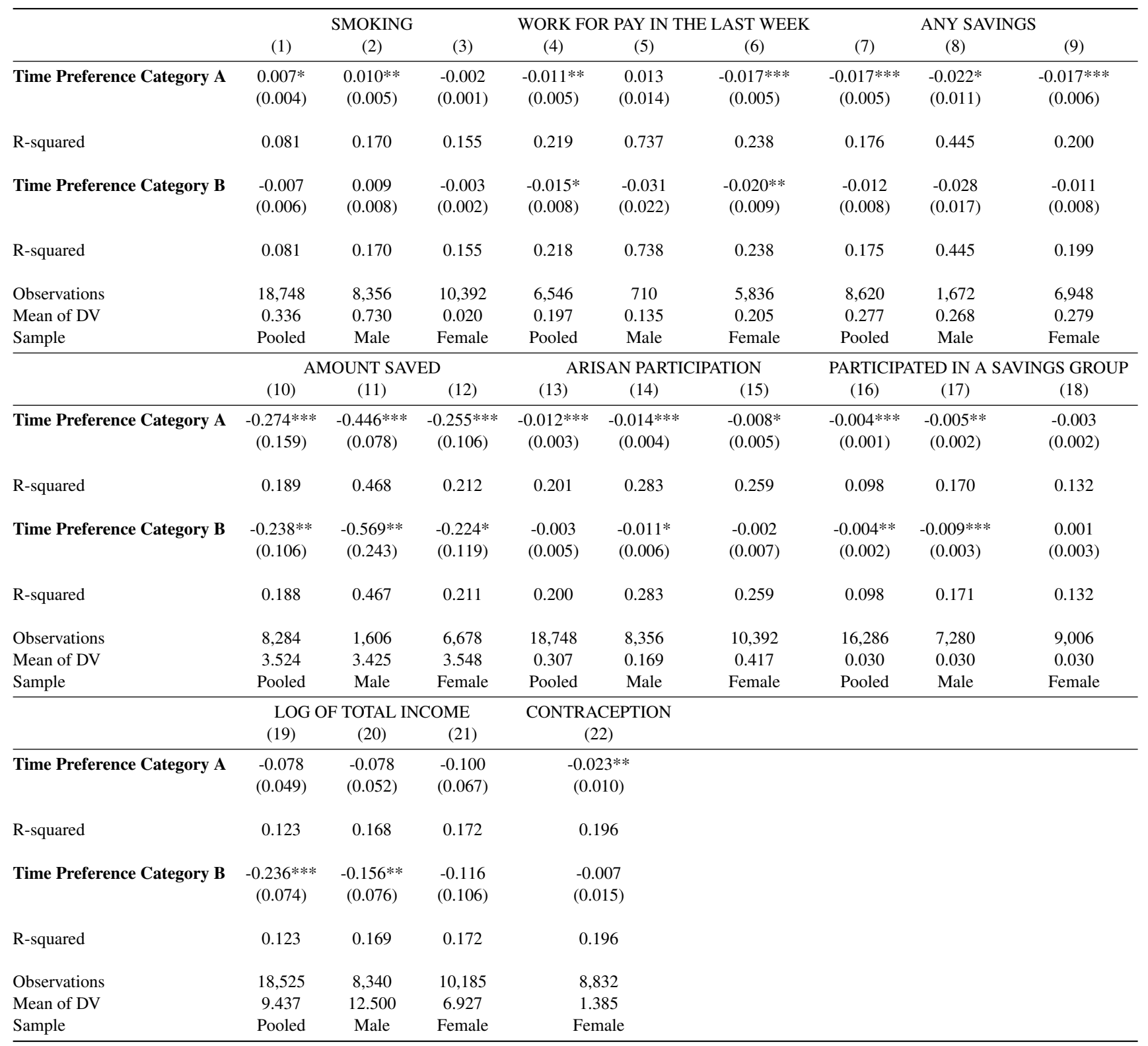

NOTE: $* p<0.1, * * p<0.05, * * * p<0.01$. Higher values of the the time preference measure variables denote higher levels of impatience. A respondent's time preference category is constructed as per Figure 1. Robust standard errors are clustered at the province level. We include controls for parental education, ethnicity, religion, birth month-year FE, district of birth FE, current district of residence FE, language used for the interview, an indicator of the order in which the respondent answered the time preference modules, rainfall in the in-utero and early-life period. 


\section{A.1 Time preference imputation}

For simplicity, we assume that individuals discount future rewards exponentially. Consider responses to TP-A. Conditional on $\beta_{T A} \leq 1$, where $\beta_{T A}$ is the individual's discount factor that she used to compare question in module TP-A, the discounted value comparison for a person who chooses IDR $1 \mathrm{~m}$ today over IDR $3 \mathrm{~m}$ one year from now must be $1 \geq \beta_{T A} * 3$. Therefore, $\beta_{T A}$ must be less than or equal to $1 / 3$. For those who choose IDR $3 \mathrm{~m}$ one year from now over IDR $1 \mathrm{~m}$ today, therefore, have $\beta_{T A} \geq 1 / 3$. Those who chose IDR $1 \mathrm{~m}$ in the first round have to choose between IDR $1 \mathrm{~m}$ today or IDR $6 \mathrm{~m}$ in one year from today in the next round. If, here, someone chooses IDR $1 \mathrm{~m}$ today, it must be that $1 \geq \beta_{T A} * 6$. This implies that $\beta_{T A} \leq 1 / 6$. Consequently, those who chose IDR $1 \mathrm{~m}$ in the first round but chose IDR $6 \mathrm{~m}$ in the second round must have $1 / 6 \leq \beta_{T A} \leq 1 / 3$. Those who choose IDR $3 \mathrm{~m}$ in the first round have to choose between IDR $1 \mathrm{~m}$ today and IDR $2 \mathrm{~m}$ tomorrow in the second round. If they prefer IDR $2 \mathrm{~m}$ here, they have $\beta_{T A} \geq 1 / 2,1 / 3 \leq \beta_{T A} \leq 1 / 2$ otherwise. We calculate the bounds on $\beta T B$ using a similar approach. The only difference is instead of using $\beta$, individual responses to module $\mathrm{B}$ uses $\beta^{5}$ because the delayed reward is five years in the future. For each individual, we calculate the midpoint of the bounds thus calculated. Then, we take an inverse of this value such that, consistent with our other dependent variables, a higher values denotes a higher level of impatience. This is the imputed time preference measure. 
Table A4: ASSOCIATION BETWEEN IMPUTED TIME PREFERENCE VALUE AND BEHAVIOR

\begin{tabular}{|c|c|c|c|c|c|c|c|c|c|}
\hline & \multicolumn{3}{|c|}{ SMOKING } & \multicolumn{3}{|c|}{ WORK FOR PAY IN THE LAST WEEK } & \multicolumn{3}{|c|}{ ANY SAVINGS } \\
\hline & (1) & (2) & (3) & (4) & (5) & (6) & (7) & (8) & (9) \\
\hline Imputated TP-A & $\begin{array}{c}0.001 \\
(0.001)\end{array}$ & $\begin{array}{c}0.003 * * * \\
(0.001)\end{array}$ & $\begin{array}{l}-0.000 \\
(0.000)\end{array}$ & $\begin{array}{c}-0.002 * * \\
(0.001)\end{array}$ & $\begin{array}{c}0.004 \\
(0.003)\end{array}$ & $\begin{array}{c}-0.003 * * * \\
(0.001)\end{array}$ & $\begin{array}{c}-0.005 * * * \\
(0.001)\end{array}$ & $\begin{array}{c}-0.006 * * \\
(0.002)\end{array}$ & $\begin{array}{c}-0.004 * * * \\
(0.001)\end{array}$ \\
\hline R-squared & 0.081 & 0.171 & 0.155 & 0.218 & 0.738 & 0.238 & 0.177 & 0.446 & 0.201 \\
\hline Imputated TP-B & $\begin{array}{l}-0.007 \\
(0.005)\end{array}$ & $\begin{array}{l}0.011^{*} \\
(0.006)\end{array}$ & $\begin{array}{l}-0.003 \\
(0.002)\end{array}$ & $\begin{array}{l}-0.009 \\
(0.007)\end{array}$ & $\begin{array}{l}-0.009 \\
(0.018)\end{array}$ & $\begin{array}{l}-0.013^{*} \\
(0.007)\end{array}$ & $\begin{array}{c}-0.019 * * * \\
(0.006)\end{array}$ & $\begin{array}{c}-0.031 * * \\
(0.015)\end{array}$ & $\begin{array}{c}-0.018^{* *} \\
(0.007)\end{array}$ \\
\hline R-squared & 0.081 & 0.170 & 0.155 & 0.218 & 0.737 & 0.237 & 0.176 & 0.446 & 0.200 \\
\hline Observations & 18,748 & 8,356 & 10,392 & 6,546 & 710 & 5,836 & 8,620 & 1,672 & 6,948 \\
\hline Mean of DV & 0.336 & 0.730 & 0.020 & 0.197 & 0.135 & 0.205 & 0.277 & 0.268 & 0.279 \\
\hline \multirow[t]{3}{*}{ Sample } & Pooled & Male & Female & Pooled & Male & Female & Pooled & Male & Female \\
\hline & \multicolumn{3}{|c|}{ AMOUNT SAVED } & \multicolumn{3}{|c|}{ ARISAN PARTICIPATION } & \multicolumn{3}{|c|}{ PARTICIPATED IN A SAVINGS GROUP } \\
\hline & $(10)$ & (11) & (12) & (13) & (14) & (15) & (16) & (17) & (18) \\
\hline Imputated TP-A & $\begin{array}{c}-0.071 * * * \\
(0.016)\end{array}$ & $\begin{array}{l}-0.104 * * * \\
(0.035)\end{array}$ & $\begin{array}{c}-0.065^{* * * *} \\
(0.017)\end{array}$ & $\begin{array}{c}-0.003 * * * \\
(0.001)\end{array}$ & $\begin{array}{c}-0.004 * * * \\
(0.001)\end{array}$ & $\begin{array}{c}-0.002 * * \\
(0.001)\end{array}$ & $\begin{array}{l}-0.001 \\
(0.000)\end{array}$ & $\begin{array}{l}-0.001 \\
(0.000)\end{array}$ & $\begin{array}{l}-0.000 \\
(0.000)\end{array}$ \\
\hline R-squared & 0.189 & 0.468 & 0.213 & 0.201 & 0.284 & 0.259 & 0.098 & 0.170 & 0.132 \\
\hline Imputated TP-B & $\begin{array}{c}-0.323^{* * *} \\
(0.090)\end{array}$ & $\begin{array}{c}-0.569 * * * \\
(0.210)\end{array}$ & $\begin{array}{c}-0.310^{* * *} \\
(0.101)\end{array}$ & $\begin{array}{l}-0.006 \\
(0.004)\end{array}$ & $\begin{array}{c}-0.012 * * \\
(0.005)\end{array}$ & $\begin{array}{l}-0.009 \\
(0.006)\end{array}$ & $\begin{array}{l}-0.003^{*} \\
(0.002)\end{array}$ & $\begin{array}{c}-0.007 * * \\
(0.003)\end{array}$ & $\begin{array}{c}0.001 \\
(0.002)\end{array}$ \\
\hline R-squared & 0.188 & 0.468 & 0.212 & 0.200 & 0.283 & 0.259 & 0.098 & 0.170 & 0.132 \\
\hline Observations & 8,284 & 1,606 & 6,678 & 18,748 & 8,356 & 10,392 & 16,286 & 7,280 & 9,006 \\
\hline Mean of DV & 3.524 & 3.425 & 3.548 & 0.307 & 0.169 & 0.417 & 0.030 & 0.030 & 0.030 \\
\hline \multirow[t]{2}{*}{ Sample } & Pooled & Male & Female & Pooled & Male & Female & Pooled & Male & Female \\
\hline & $\begin{array}{l}\text { LOG O } \\
\text { (19) }\end{array}$ & $\begin{array}{l}\text { F TOTAL IN } \\
\quad(20)\end{array}$ & $\begin{array}{l}\text { COME } \\
(21)\end{array}$ & \multicolumn{2}{|c|}{$\begin{array}{l}\text { CONTRACEPTION } \\
\text { (22) }\end{array}$} & & & & \\
\hline Imputated TP-A & $\begin{array}{c}-0.024 * * \\
(0.011)\end{array}$ & $\begin{array}{l}-0.016 \\
(0.011)\end{array}$ & $\begin{array}{l}-0.025^{*} \\
(0.015)\end{array}$ & $\begin{array}{r}-0.00 \\
(0.0\end{array}$ & $\begin{array}{l}6 * * * \\
02)\end{array}$ & & & & \\
\hline R-squared & 0.123 & 0.168 & 0.172 & 0.1 & & & & & \\
\hline Imputated TP-B & $\begin{array}{c}-0.232 * * * \\
(0.062)\end{array}$ & $\begin{array}{c}-0.139 * * \\
(0.064)\end{array}$ & $\begin{array}{l}-0.150^{*} \\
(0.088)\end{array}$ & $\begin{array}{l}-0 . \\
(0.0\end{array}$ & & & & & \\
\hline R-squared & 0.123 & 0.169 & 0.172 & 0.1 & & & & & \\
\hline Observations & 18,525 & 8,340 & 10,185 & 8,8 & & & & & \\
\hline Mean of DV & 9.437 & 12.500 & 6.927 & 1.3 & & & & & \\
\hline Sample & Pooled & Male & Female & Fen & & & & & \\
\hline
\end{tabular}

NOTE: $* p<0.1, * * p<0.05, * * * p<0.01$. Higher values of the time preference measure denote higher levels of impatience. The imputed value of time preference is calculated using the method detailed in A.1. Robust standard errors are clustered at the province level. We include controls for parental education, ethnicity, religion, birth month-year FE, district of birth FE, current district of residence FE, language used for the interview, an indicator of the order in which the respondent answered the time preference modules, rainfall in the in-utero and early-life period. 
Table A5: IV-2SLS 1ST STAGE - ASSOCIATION BETWEEN INPRES EXPOSURE AND SCHOOLING

\begin{tabular}{lcccccc}
\hline & \multicolumn{7}{c}{ YEARS OF SCHOOLING } \\
& $(1)$ & $(2)$ & $(3)$ & $(4)$ & $(5)$ & $(6)$ \\
\hline Intensity * Treated cohort dummy & 0.315 & 0.053 & $0.578^{*}$ & $0.277^{* *}$ & 0.004 & $0.747^{* * *}$ \\
& $(0.230)$ & $(0.290)$ & $(0.281)$ & $(0.124)$ & $(0.360)$ & $(0.221)$ \\
& & & & & & \\
Duflo (2001) controls & $\mathrm{Y}$ & $\mathrm{Y}$ & $\mathrm{Y}$ & $\mathrm{Y}$ & $\mathrm{Y}$ & $\mathrm{Y}$ \\
Duflo (2001) + additional controls & $\mathrm{N}$ & $\mathrm{N}$ & $\mathrm{N}$ & $\mathrm{Y}$ & $\mathrm{Y}$ & $\mathrm{Y}$ \\
Sample & Pooled & Male & Female & Pooled & Male & Female \\
& & & & & & \\
Observations & 3,187 & 1,626 & 1,561 & 3,005 & 1,541 & 1,464 \\
R-squared & 0.274 & 0.333 & 0.351 & 0.602 & 0.715 & 0.698 \\
\hline
\end{tabular}

NOTE: $* p<0.1$, ** $p<0.05$, *** $p<0.01$. Intensity is the number of schools constructed per 1,000 students varied by district level. Treated cohort dummy takes value ' 1 ' if the individual was born between 1968 and 1972 and ' 0 ' if the individual was born between 1958 and 1962. Robust standard errors are clustered at the province level. The controls are the same as those used in Table 3.

Table A6: ROBUSTNESS OF IV-2SLS RESULTS FOR FEMALES TO DIFFERENT FIXED-EFFECT SPECIFICATIONS

\begin{tabular}{lccccccccc}
\hline & \multicolumn{3}{c}{ TIME PREFERENCE A } & \multicolumn{3}{c}{ TIME PREFERENCE B } & \multicolumn{3}{c}{ COMPOSITE MEASURE } \\
& $(1)$ & $(2)$ & $(3)$ & $(4)$ & $(5)$ & $(6)$ & $(7)$ & $(8)$ & $(9)$ \\
\hline IV-2SLS (N=1,464) & & & & & & & & & \\
Years of schooling & -0.012 & -0.002 & -0.048 & $-0.094^{* * *}$ & $-0.070^{*}$ & $-0.134^{* *}$ & $-0.196^{*}$ & -0.120 & $-0.275^{* * *}$ \\
& $(0.045)$ & $(0.032)$ & $(0.055)$ & $(0.034)$ & $(0.042)$ & $(0.066)$ & $(0.117)$ & $(0.108)$ & $(0.094)$ \\
& & & & & & & & & \\
Year*Month FE & $\mathrm{Y}$ & $\mathrm{N}$ & $\mathrm{N}$ & $\mathrm{Y}$ & $\mathrm{N}$ & $\mathrm{N}$ & $\mathrm{Y}$ & $\mathrm{N}$ & $\mathrm{N}$ \\
Year of Birth FE & $\mathrm{N}$ & $\mathrm{Y}$ & $\mathrm{Y}$ & $\mathrm{N}$ & $\mathrm{Y}$ & $\mathrm{Y}$ & $\mathrm{N}$ & $\mathrm{Y}$ & $\mathrm{Y}$ \\
Month of Birth FE & $\mathrm{N}$ & $\mathrm{Y}$ & $\mathrm{Y}$ & $\mathrm{N}$ & $\mathrm{Y}$ & $\mathrm{Y}$ & $\mathrm{N}$ & $\mathrm{Y}$ & $\mathrm{Y}$ \\
Interviewer FE & $\mathrm{N}$ & $\mathrm{N}$ & $\mathrm{Y}$ & $\mathrm{N}$ & $\mathrm{N}$ & $\mathrm{Y}$ & $\mathrm{N}$ & $\mathrm{N}$ & $\mathrm{Y}$ \\
& & & & & & & & & \\
IV F-stat & 11.47 & 12.59 & 2.2 & 11.47 & 12.59 & 2.2 & 11.47 & 12.59 & 2.2 \\
Observations & 1,464 & 1,464 & 1,464 & 1,464 & 1,464 & 1,464 & 1,464 & 1,464 & 1,464 \\
Mean DV & 0.684 & 0.684 & 0.684 & 0.796 & 0.796 & 0.796 & -0.007 & -0.007 & -0.007 \\
Mean Years of Schooling & 8.592 & 8.592 & 8.592 & 8.592 & 8.592 & 8.592 & 8.592 & 8.592 & 8.592 \\
\hline
\end{tabular}

NOTE: $* p<0.1, * * p<0.05, * * * p<0.01$. Higher values of the dependent variables denote higher levels of impatience. Intensity is the number of schools constructed per 1,000 students varied by district level. Treated cohort dummy takes value ' 1 ' if the individual was born between 1968 and 1972 and ' 0 ' if the individual was born between 1958 and 1962. Robust standard errors are clustered at the province level. The controls are the same as those used in Table 3. 
Table A7: IMPACT OF EDUCATION ON TIME PREFERENCE (POOLED AND THE MALE SAMPLES)

\begin{tabular}{|c|c|c|c|c|c|c|}
\hline & $\begin{array}{c}\text { TIME } \\
\text { PREFERENCE A }\end{array}$ & $\begin{array}{c}\text { TIME } \\
\text { PREFERENCE B }\end{array}$ & $\begin{array}{l}\text { COMPOSITE } \\
\text { MEASURE }\end{array}$ & $\begin{array}{c}\text { TIME } \\
\text { PREFERENCE A }\end{array}$ & $\begin{array}{c}\text { TIME } \\
\text { PREFERENCE B }\end{array}$ & $\begin{array}{l}\text { COMPOSITE } \\
\text { MEASURE }\end{array}$ \\
\hline & \multicolumn{6}{|c|}{ ORDINARY LEAST SQUARES (OLS) MODEL } \\
\hline Years of schooling & $\begin{array}{c}-0.008^{* * *} \\
(0.002)\end{array}$ & $\begin{array}{c}-0.004 * * * \\
(0.001)\end{array}$ & $\begin{array}{c}-0.009^{*} \\
(0.005)\end{array}$ & $\begin{array}{c}-0.016^{* * *} \\
(0.004)\end{array}$ & $\begin{array}{c}-0.009^{* * *} \\
(0.002)\end{array}$ & $\begin{array}{c}-0.029 * * * \\
(0.010)\end{array}$ \\
\hline R-squared & 0.074 & 0.077 & 0.069 & 0.149 & 0.142 & 0.150 \\
\hline \multirow[b]{2}{*}{ Years of schooling } & \multicolumn{6}{|c|}{ INSTRUMENTAL VARIABLE (IV) MODEL } \\
\hline & $\begin{array}{l}-0.018 \\
(0.060)\end{array}$ & $\begin{array}{l}-0.072 \\
(0.080)\end{array}$ & $\begin{array}{l}-0.113 \\
(0.166)\end{array}$ & $\begin{array}{c}-13.361 \\
(911.521)\end{array}$ & $\begin{array}{c}-12.566 \\
(855.759)\end{array}$ & $\begin{array}{c}-36.209 \\
(2474.882)\end{array}$ \\
\hline IV First stage $\mathrm{F}$ & 4.98 & 4.98 & 4.98 & 0.00 & 0.00 & 0.00 \\
\hline $\begin{array}{c}\text { Observations } \\
\text { Mean DV }\end{array}$ & 3,005 & 3,005 & $\begin{array}{c}3,005 \\
-0.009\end{array}$ & 1,541 & 1,541 & $\begin{array}{c}1,541 \\
-0.007\end{array}$ \\
\hline Mean YoS & 9.011 & 9.011 & 9.011 & 9.409 & 9.409 & 9.409 \\
\hline Sample & Pooled & Pooled & Pooled & Male & Male & Male \\
\hline
\end{tabular}

NOTE: $* p<0.1$, ** $p<0.05, * * * p<0.01$. Higher values of the dependent variables denote higher levels of impatience. Robust standard errors are clustered at the province level. The specification and all controls are the same as those used in Table 3.

Table A8: IMPACT OF EDUCATION ON BEHAVIOR (POOLED AND MALES SAMPLE)

\begin{tabular}{|c|c|c|c|c|c|c|c|}
\hline & SMOKING & $\begin{array}{l}\text { WORK } \\
\text { FOR PAY }\end{array}$ & $\begin{array}{c}\text { ANY } \\
\text { SAVING }\end{array}$ & $\begin{array}{l}\text { AMOUNT } \\
\text { SAVED }\end{array}$ & $\begin{array}{c}\text { ARISAN } \\
\text { PARTICIPATION }\end{array}$ & $\begin{array}{l}\text { PARTICIPATED IN } \\
\text { SAVINGS GROUP }\end{array}$ & $\begin{array}{c}\text { LOG OF } \\
\text { TOTAL INCOME }\end{array}$ \\
\hline \multirow[b]{2}{*}{ Years of schooling } & \multicolumn{7}{|c|}{ POOLED SAMPLE } \\
\hline & $\begin{array}{l}-0.021 \\
(0.051)\end{array}$ & $\begin{array}{l}0.092 * * \\
(0.036)\end{array}$ & $\begin{array}{c}0.023 \\
(0.049)\end{array}$ & $\begin{array}{l}-0.009 \\
(0.103)\end{array}$ & $\begin{array}{c}0.135 \\
(0.082)\end{array}$ & $\begin{array}{l}-0.016 \\
(0.043)\end{array}$ & $\begin{array}{c}1.345 \\
(0.918)\end{array}$ \\
\hline Observations & 2,593 & 3,005 & 3,005 & 3,005 & 3,005 & 2,645 & 2,970 \\
\hline Mean of DV & 0.391 & 0.074 & 0.139 & 0.349 & 0.389 & 0.053 & 10.900 \\
\hline Mean of YoS & 9.064 & 9.011 & 9.011 & 9.011 & 9.011 & 8.859 & 9.023 \\
\hline IV F-stat & 4.851 & 4.976 & 4.976 & 4.976 & 4.976 & 5.816 & 4.639 \\
\hline & \multicolumn{7}{|c|}{ MALE SAMPLE } \\
\hline Years of schooling & $\begin{array}{l}-0.051 \\
(0.077)\end{array}$ & $\begin{array}{c}-1.801 \\
(124.375)\end{array}$ & $\begin{array}{c}3.386 \\
(231.111)\end{array}$ & $\begin{array}{c}14.904 \\
(1,013.703)\end{array}$ & $\begin{array}{c}-1.359 \\
(89.421)\end{array}$ & $\begin{array}{c}0.444 \\
(3.208)\end{array}$ & $\begin{array}{c}86.314 \\
(3,331.249)\end{array}$ \\
\hline Observations & 1,292 & 1,541 & 1,541 & 1,541 & 1,541 & 1,376 & 1,538 \\
\hline Mean of DV & 0.748 & 0.026 & 0.042 & 0.102 & 0.236 & 0.046 & 12.833 \\
\hline Mean of YoS & 9.526 & 9.409 & 9.409 & 9.409 & 9.409 & 9.264 & 9.414 \\
\hline IV F-stat & 0.749 & 0.0001 & 0.0001 & 0.0001 & 0.0001 & 0.012 & 0.0003 \\
\hline
\end{tabular}

NOTE: $* p<0.1,{ }^{*} p<0.05, * * * p<0.01$. Robust standard errors are clustered at the province level. The specification and all controls are the same as those used in Table 3. 


\section{B Individual fixed-effect specification}

Since the response to the time preference questions in collected in both wave 4 (2007) and wave 5 (2014) of the IFLS, we can examine how the changes in years of schooling across waves affected the time preference of individuals. For the analysis, we retain observations for only those individuals who answered the time preference questions in the two waves and saw a zero or positive change in their education level between the two waves. Since the IFLS administered the time preference module to only those fifteen years of age or older and those above twenty-five rarely saw a change in their years of schooling, we restrict the analysis to those fifteen to twenty-five years old in 2007 . We examine the association using the following specification.

$$
Y_{i c t}=\alpha+\beta S_{i c t}+\lambda_{i}+\eta_{t}+\eta_{i c t}
$$

The summary statistics for the fixed-effects sample is presented in Table B1 and the associations are presented in Table B3. The estimated coefficients are consistent with the IV results in their direction. None of them are significant. However, it is important to remember that individuals fifteen years or older who see a change in their years of schooling might most-likely be getting more secondary or tertiary education. If, as Figure 2 and the IV estimates suggest, the impact of education on time preference is largest at the level of primary education, the lack of significance and the smaller magnitudes might be consistent with the IV result. But since the standard errors are fairly large, we cannot claim anything with certainty.

Table B1: SUMMARY STATISTICS (FIXED EFFECT SAMPLE)

\begin{tabular}{|c|c|c|c|c|}
\hline & \multicolumn{2}{|c|}{ IFLS WAVE 4} & \multicolumn{2}{|c|}{ IFLS WAVE 5} \\
\hline & MALE $(\mathrm{N}=920)$ & FEMALE $(\mathrm{N}=1,141)$ & $\operatorname{MALE}(\mathrm{N}=920)$ & FEMALE $(\mathrm{N}=1142)$ \\
\hline & \multicolumn{4}{|c|}{ PERCENTAGE RESPONDENTS } \\
\hline \multicolumn{5}{|l|}{ Time Preference A } \\
\hline 1 ( = Most patient) & 0.109 & 0.106 & 0.124 & 0.130 \\
\hline 2 & 0.075 & 0.106 & 0.087 & 0.098 \\
\hline 3 & 0.208 & 0.172 & 0.159 & 0.198 \\
\hline 4 ( = Most Impatient) & 0.609 & 0.615 & 0.630 & 0.573 \\
\hline \multicolumn{5}{|l|}{ Time Preference B } \\
\hline 1 ( = Most patient) & 0.020 & 0.024 & 0.025 & 0.020 \\
\hline 2 & 0.048 & 0.053 & 0.072 & 0.054 \\
\hline 3 & 0.187 & 0.177 & 0.209 & 0.232 \\
\hline 4 ( = Most Impatient) & 0.746 & 0.746 & 0.695 & 0.693 \\
\hline
\end{tabular}

NOTE: The sample consists of individuals who witnessed a zero or positive increase in educational attainment between wave 4 and wave 5 of the IFLS. 
Table B2: INDIVIDUAL FIXED EFFECTS MODEL (FEMALES)

TIME PREFERENCE A TIME PREFERENCE B COMPOSITE MEASURE

\begin{tabular}{|c|c|c|c|}
\hline \multirow[b]{2}{*}{ Years of schooling } & \multicolumn{3}{|c|}{ ORDINARY LEAST SQUARES (OLS) MODEL } \\
\hline & $\begin{array}{c}-0.019 * * * \\
(0.006)\end{array}$ & $\begin{array}{c}-0.019 * * * \\
(0.004)\end{array}$ & $\begin{array}{c}-0.047 * * * \\
(0.015)\end{array}$ \\
\hline R-squared & 0.174 & 0.156 & 0.172 \\
\hline \multirow[b]{2}{*}{ Years of schooling } & \multicolumn{3}{|c|}{ INDIVIDUAL FIXED EFFECTS (FE) MODEL } \\
\hline & $\begin{array}{l}-0.007 \\
(0.016)\end{array}$ & $\begin{array}{l}-0.020 \\
(0.016)\end{array}$ & $\begin{array}{c}-0.026 \\
(0.046)\end{array}$ \\
\hline R-squared & 0.634 & 0.658 & 0.680 \\
\hline Observations & 2,282 & 2,282 & 2,282 \\
\hline Mean DV & 0.594 & 0.720 & -0.209 \\
\hline Mean YoS & 10.430 & 10.430 & 10.430 \\
\hline
\end{tabular}

NOTE: $* p<0.1$, ** $p<0.05$, *** $p<0.01$. Higher values of the dependent variables denote higher levels of impatience. Robust standard errors are clustered at the province level. The sample consists of individuals who witnessed a zero or positive increase in educational attainment between wave 4 and wave 5 of the IFLS. For the OLS specifications, we include controls for parental education, ethnicity, religion, birth month-year FE, district of birth FE, current district of residence FE, language used for the interview, an indicator of the order in which the respondent answered the time preference modules, rainfall in the in-utero and early-life period. For individual FE analysis, we do not need to control time invariant observables. 
Table B3: INDIVIDUAL FIXED EFFECTS MODEL (FEMALES) WITH TIME PREFERENCE CATEGORIES AND IMPUTED VALUES AS OUTCOMES

\begin{tabular}{lcccc}
\hline & CATEGORY TP-A & IMPUTED TP-A & CATEGORY TP-B & IMPUTED TP-B \\
\hline Years of schooling & -0.019 & -0.068 & -0.012 & -0.033 \\
& $(0.042)$ & $(0.162)$ & $(0.029)$ & $(0.029)$ \\
R-squared & & & & \\
Observations & 0.671 & 0.676 & 0.662 & 0.659 \\
Mean of DV & 2,282 & 2,282 & 2,282 & 2,282 \\
Mean of Years of Schooling & 0.594 & 0.594 & 0.720 & 0.720 \\
\hline
\end{tabular}

NOTE: $* p<0.1$, ** $p<0.05$, *** $p<0.01$. Higher values of the dependent variables denote higher levels of impatience. The sample consists of individuals who witnessed a zero or positive increase in educational attainment between wave 4 and wave 5 of the IFLS. A respondent's time preference category is constructed as per Figure 1. The imputed value of time preference is calculated using the method detailed in A.1. Robust standard errors are clustered at the province level.

Table B4: FIXED EFFECTS MODEL (POOLED AND MALE SAMPLES)

\begin{tabular}{|c|c|c|c|c|c|c|}
\hline & $\begin{array}{c}\text { TIME } \\
\text { PREFERENCE A } \\
(1)\end{array}$ & $\begin{array}{c}\text { TIME } \\
\text { PREFERENCE B } \\
(2)\end{array}$ & $\begin{array}{l}\text { COMPOSITE } \\
\text { MEASURE } \\
\text { (3) }\end{array}$ & $\begin{array}{c}\text { TIME } \\
\text { PREFERENCE A } \\
(4)\end{array}$ & $\begin{array}{c}\text { TIME } \\
\text { PREFERENCE B } \\
(5)\end{array}$ & $\begin{array}{c}\text { COMPOSITE } \\
\text { MEASURE } \\
(6)\end{array}$ \\
\hline \multirow[b]{2}{*}{ Years of schooling } & \multicolumn{6}{|c|}{ ORDINARY LEAST SQUARES (OLS) MODEL } \\
\hline & $\begin{array}{l}-0.019 * * * \\
(0.006)\end{array}$ & $\begin{array}{c}-0.015^{* * *} \\
(0.003)\end{array}$ & $\begin{array}{c}-0.042 * * * \\
(0.013)\end{array}$ & $\begin{array}{c}-0.019 * * * \\
(0.006)\end{array}$ & $\begin{array}{c}-0.012 * * * \\
(0.004)\end{array}$ & $\begin{array}{c}-0.033 * * \\
(0.011)\end{array}$ \\
\hline \multirow[t]{2}{*}{ R-squared } & 0.129 & 0.124 & 0.133 & 0.218 & 0.208 & 0.223 \\
\hline & \multicolumn{6}{|c|}{ INDIVIDUAL FIXED EFFECTS (FE) MODEL } \\
\hline Years of schooling & $\begin{array}{l}-0.006 \\
(0.014)\end{array}$ & $\begin{array}{l}-0.017 \\
(0.013)\end{array}$ & $\begin{array}{l}-0.025 \\
(0.039)\end{array}$ & $\begin{array}{l}-0.001 \\
(0.027)\end{array}$ & $\begin{array}{l}-0.014 \\
(0.026)\end{array}$ & $\begin{array}{l}-0.027 \\
(0.067)\end{array}$ \\
\hline R-squared & 0.631 & 0.633 & 0.643 & 0.673 & 0.678 & 0.674 \\
\hline Observations & 4,122 & 4,122 & 4,122 & 1,840 & 1,840 & 1,840 \\
\hline Observations & Pooled & Pooled & Pooled & Male & Male & Male \\
\hline Mean DV & 0.606 & 0.720 & -0.196 & 0.620 & 0.720 & -0.181 \\
\hline Mean YoS & 10.437 & 10.437 & 10.437 & 10.445 & 10.445 & 10.445 \\
\hline \multicolumn{7}{|c|}{$\begin{array}{l}\text { NOTE: } * p<0.1, * * p<0.05, * * * p<0.01 \text {. Higher values of the dependent variables denote higher levels of impatience. Robust } \\
\text { standard errors are clustered at the province level. The sample consists of individuals who witnessed a zero or positive increase in educational } \\
\text { attainment between wave } 4 \text { and wave } 5 \text { of the IFLS. For the OLS specifications, we include controls for parental education, ethnicity, religion, } \\
\text { birth month-year FE, district of birth FE, current district of residence FE, language used for the interview, an indicator of the order in which } \\
\text { the respondent answered the time preference modules, rainfall in the in-utero and early-life period. For individual FE analysis, we do not need } \\
\text { to control time invariant observables. }\end{array}$} \\
\hline
\end{tabular}




\section{Potential Pathways}

In this section, we examine potential pathways via which education might affect time preference and provide suggestive evidence from four different methods of mediation analysis detailed below. The pathways we consider do not form an exhaustive list and the supporting evidence we provide are suggestive at best. However, these associations provide important details to the cause-and-effect story of education and time preference. They might also provide testable hypotheses for future research on the topic.

The pathways we examine are total income, cognitive ability, risk aversion, self-reported health, and mental health. for every individual, the total income variable aggregates reported monthly salary or wage, net profits from businesses owned, rental income, non-labor income and retirement pension receipts, if any. We use several variables to measure the different dimensions of cognition. For fluid intelligence, we use the number of correct responses to a version of the Raven's progressive matrices included in the IFLS's cognition module to construct a score variable that ranges from 0 to 8 . We also use the arithmetic questions from the module as another measure of cognition that takes a value between 0 and 5. We use information on performance on delayed and immediate word recall (score range 0-20) and the serial sevens subtraction test (score range of 0-5) as other measures of cognition. IFLS also collects information about risk preference using hypothetical questions about lottery rewards. Based on the responses to these questions, we categorize individuals into two categories - 'risk averse' and 'others'. The self-health measure takes value ' 1 ' if the respondent finds herself very healthy, ' 0 ' otherwise. For mental, we use the Center for Epidemiological Studies Depression (CES-D) 10-items score (0-30) to construct a measure of depressive symptoms.

Most mediation analysis seek to explain how much of the variation in an outcome variable of interest (here, time preference) due to variation in the independent variable of interest (here, years of education) is explained by variation in the mediator variable of interest (for example, cognition) due to variations in the independent variable. We use four of the popular methods. While each method makes several strong assumption and has its own weaknesses, we believe that this exercise might, nonetheless, be informative. But the findings from this section must be interpreted with caution.

1. Mediation Analysis 1 (MacKinnon et al. (2007); Maccini and Yang (2009)): Here, we include the endogenous mechanism variable as a regressor along with the independent variable of interest. If the inclusion of a particular mechanism variable dampens the association between years of education and the measure of time preference substantially and is itself strongly correlated with the time preference measure, it suggests that this mechanism variable is soaking away the variation in the time preference measure that covaries with education. If the adjusted $R^{2}$, the goodness-of-fit statistic of the model also rises, the likelihood of this possibility as a mechanism becomes higher. We report the results in Table $\mathrm{C} 1$.

2. Mediation Analysis 2 (Imai et al. (010b); Imai et al. (010a)): The method assumes that once the observable predetermined variables that cause variation in the independent variable of interest are controlled for, it is as if the remaining variation in the independent variable is randomly assigned and does not depend on the potential effect it will have on the outcome of interest or mediator of interest.

For this analysis, we first obtain the residual variation in the outcome variable, mediator variable, and independent variable of independent that is not explained by the observable predetermined controls. Next, by comparing the association between each pair of residuals, the method detailed in Imai et al. (010b) calculates a measure of the association between time preference and years of schooling that is through the association between the mediator variable and years of schooling. The results are presented in Table C2. For example, 30 to 40 percent of the association between years of education and time preference is via the association between years of schooling and the dimension of cognitive and problem-solving aptitude captured by the responses to the questions on the arithmetic test.

3. Mediation Analysis 3 (Heckman et al. (2013); Huber (2014)): Compared to Imai et al. (010b), this method relaxes the assumption of conditional independence of mediators. Here, the associations between the residual variation in time preference, years of schooling, and one mediator variable 
at a time are compared where the residuals are calculated by controlling for both predetermined variables and other possible mediators. The analysis also uses an inverse probability weighted calculated from the predicted value of the independent variable based on the instrumental variable. Following this approach, we calculate the percentage contribution of mechanism variables to the total effect of education TP-B in Figure C1

4. Joint Bootstrap Analysis (Bennett et al. (2018)): Here, we jointly bootstrap the association between years of schooling and time preference against the association between the years of schooling and the mechanism variable of interest. Figures $\mathrm{C} 2$ and $\mathrm{C} 3$ show the scatter plot of bootstrapped replication coefficients. The Y-axis measures the correlation between years of schooling and time preference measure $\mathrm{B}$ and the $\mathrm{X}$-axis measures the estimated correlation between years of schooling and the relevant mechanism. For example, according to panel (a) in figure $\mathrm{C} 2$, when we draw random sub-samples with replacement from the full sample, the samples where there is a higher negative association between years of schooling and impatience also have a higher positive correlation between years of schooling and performance on the Raven's test.

A couple of observations stand out. One, even when taken together, the mediators do not explain a lot of the association between education and time preference. This could be because of three possibilities. First, there are multiple other channels through which education affects time preference besides the ones we consider. Second, perhaps the mediator variables are measured with large errors or are bad measures of the mechanisms we expect them to capture. For example, consider that those with high levels of education also have high levels of cognition. But suppose that the design of the Raven's test is such that those with high levels of education and cognition fail to do well on the tests. We will categorize them as individuals with low cognition. As a result, even if variation in years of education is associated with variations in time preference through variations in 'real' level of cognition, measured variation in cognition, since it has measurement error and, as a result, does not vary with education, the mediator variable will not absorb the variation in the outcome variable due to the independent variable. A third possibility is that of reverse causation. If time preference affects both education and the mediator variable but the directions and magnitudes these effects are different, it can be difficult to conjecture whether the mediator will absorb variations in the time preference variable in a way that it reduces the level of association between time preference and years of schooling. For these reasons, we want re-emphasize that these associations are suggestive at best.

Keeping in mind these weaknesses, a second observation is that regardless of the method we choose, cognition, as measured by the Raven's test score and arithmetic scores, and, to a lesser extent, income and risk-aversion consistently turn up as important channels through which education is associated with time preference. Previous studies in economics and psychology have found a positive association between education and cognition (Black et al. (2011); Falch and Sandgren Massih (2011); Green and Riddell (2012); Carlsson et al. (2015): Ceci and Williams (1997)). According to Kahneman and Tversky (1981) and Read et al. (1999), individuals with better cognition are more likely to be future-oriented and patient. ${ }^{20}$ The positive relationship between patience and cognition is also well-established (de Wit et al. (2007); Dohmen et al. (2011)). We may conjecture that cognition might play a role in linking education and time preference.

This conjecture is supported by medical findings indicating that dorsolateral prefrontal cortex, the area of the brain that governs the executive functions like working memory, cognitive flexibility, planning (Kaplan et al. (2016); Miller and Cummings (2017)), abstract reasoning, inhibition (Miller and Cummings (2017)), and decision making (Duncan and Owen (2000)), is closely links an individual's cognition and patience. ${ }^{21}$ Dorsolateral prefrontal cortex is malleable and continues the development until adulthood. As per Rzezak et al. (2015), education might improve and protect the functioning of the dorsolateral prefrontal cortex. Thus, education might causally affect patience through its positive impact on the functioning of dorsolateral prefrontal cortex captured in measures of cognition.

\footnotetext{
${ }^{20}$ According to Dohmen et al. (2010), emotions and cognition are both important factors in decision-making. When cognition dominates emotions, individuals are likely to take a longer-run view.

${ }^{21}$ According to Duncan and Owen (2000), people with damage in the dorsolateral prefrontal cortex area have problems calculating costs and benefits of alternative choices. Damage in this area could also lead to cases where an individual is tempted to select sub-optimal options by choosing the rewards delivered immediately (Knoch and Fehr (2007)).
} 
We find that higher income and lower levels of risk-aversion could be other potential pathways. These findings are also consistent with previous studies that find wealthier (Becker and Mulligan (1997), Benjamin et al. (2013)) and risk-loving individuals are more patient (Falk et al. (2018)). Some of these mechanisms could also be interlinked. For example, Mani et al. (2013) find that mental preoccupations regarding pressing budgetary concerns can exhaust cognitive resources and hamper mental functioning. In related work, Lichand and Mani (2016) find that perceived rainfall risks through their affected on expected income and liquidity can affect cognitive functioning, memory, impulse control, susceptibility to a variety of behavioral biases including present bias in decisions. To the extent that education is associated with higher incomes, education can affect cognitive functioning through its effect on income and liquidity constraints, which in turn might affect time preference. 
Figure C1: CONTRIBUTION OF THE MEDIATOR VARIABLE AS PER MEDIATION ANALAYSIS 3

(a) TIME PREFERENCE A

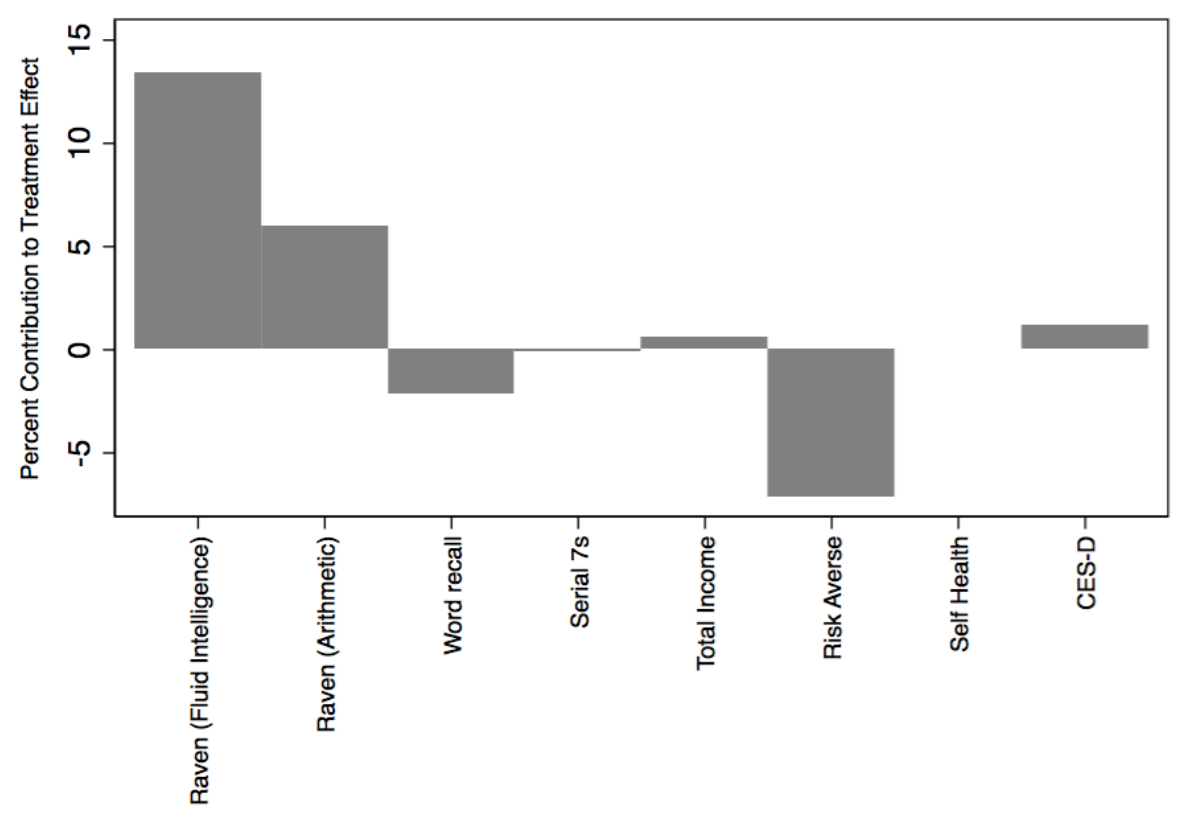

(b) TIME PREFERENCE B

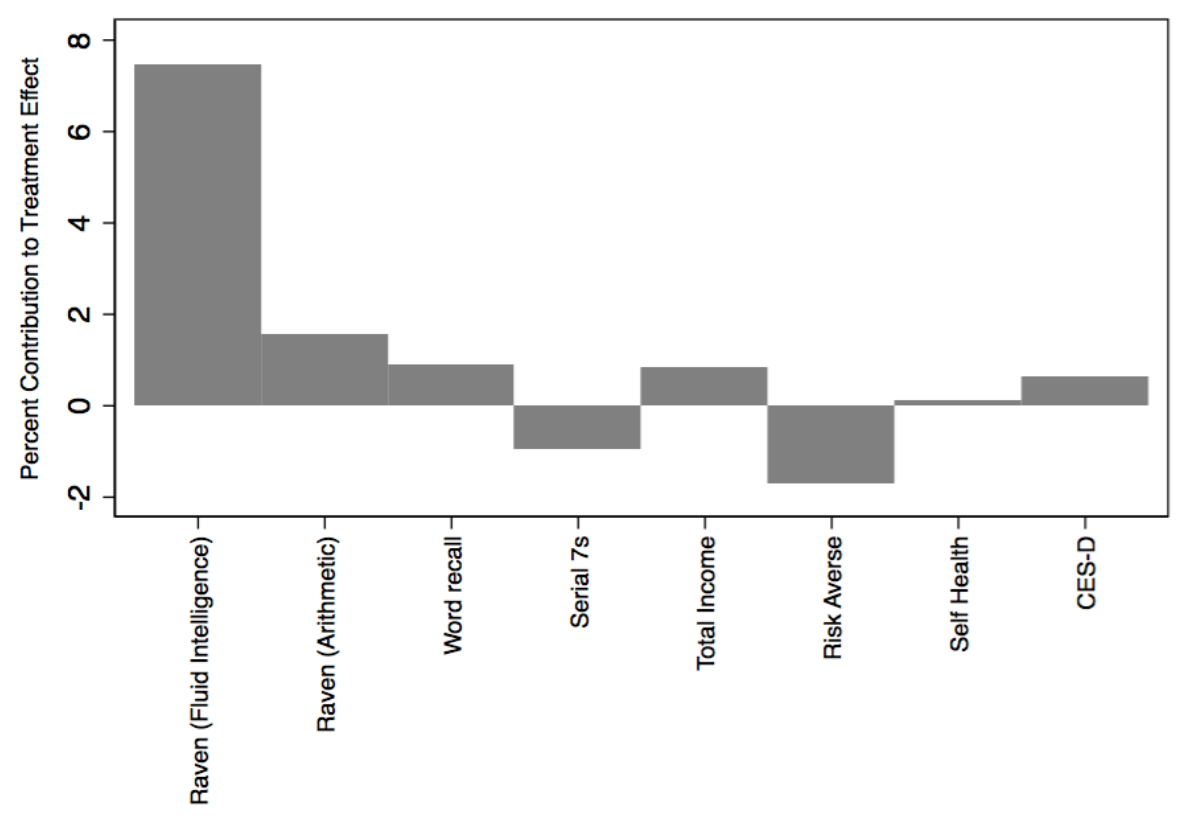

NOTE: The figures depict the percent contribution of each mediator variable when included separately. 
Figure C2: ASSOCIATION BETWEEN THE IMPACT OF EDUCATION ON TP-B AND THE IMPACT OF EDUCATION ON THE MEDIATOR VARIABLE IN BOOTSTRAPPED SAMPLES (PANEL 1)

(a) RAVEN'S TEST SCORE

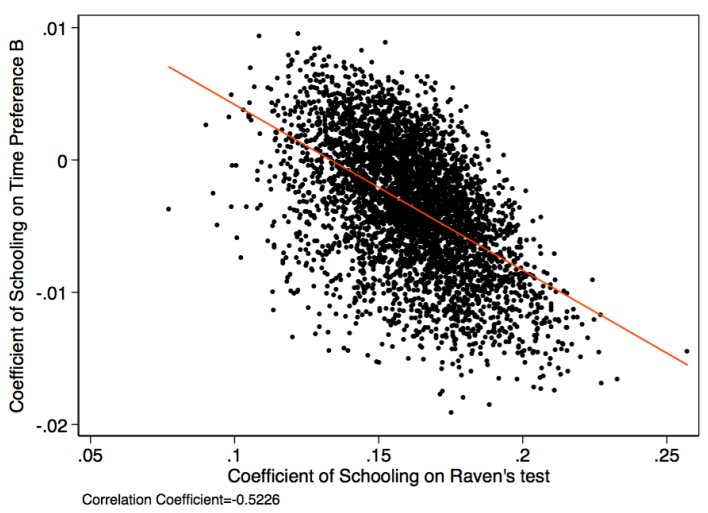

(c) TOTAL WORD RECALL

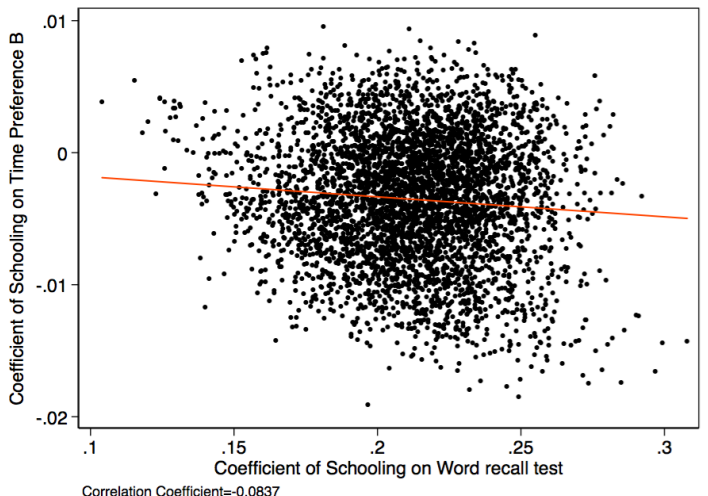

(b) ARITHMETIC TEST

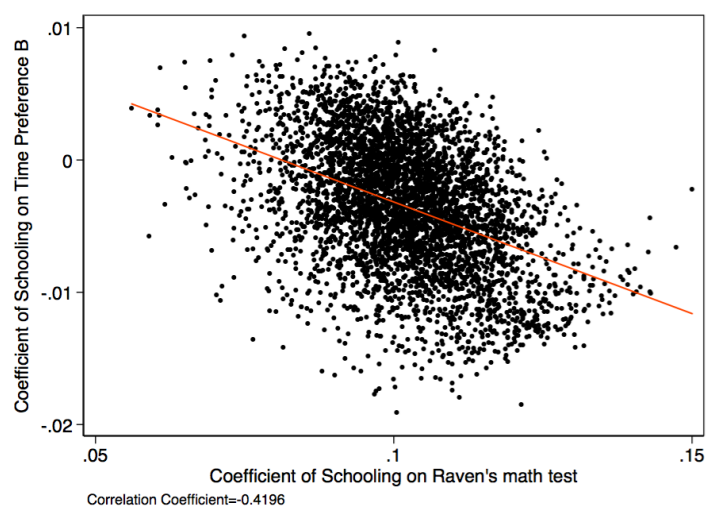

(d) SERIAL 7 SUBTRACTION

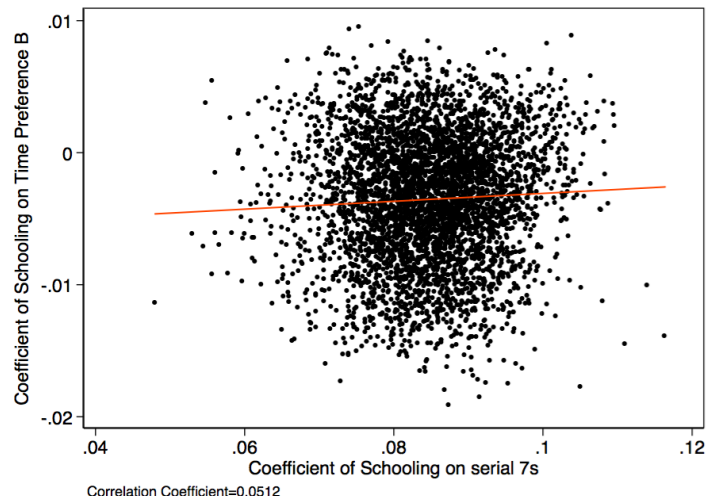

Correlation Coefficient $=0.0512$

NOTE: The figures plot the conditional correlation coefficients between education and time preference measure B against the correlation between education and the mediator variables for 100 random samples drawn from the main sample with replacement. // 
Figure C3: ASSOCIATION BETWEEN THE IMPACT OF EDUCATION ON TP-B AND THE IMPACT OF EDUCATION ON THE MEDIATOR VARIABLE IN BOOTSTRAPPED SAMPLES (PANEL 2)

(a) TOTAL INCOME

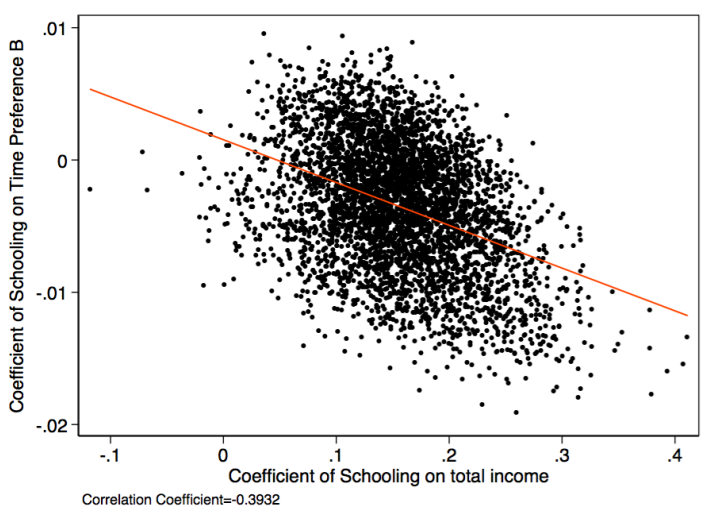

(c) SELF HEALTH EVALUATION - VERY HEALTHY

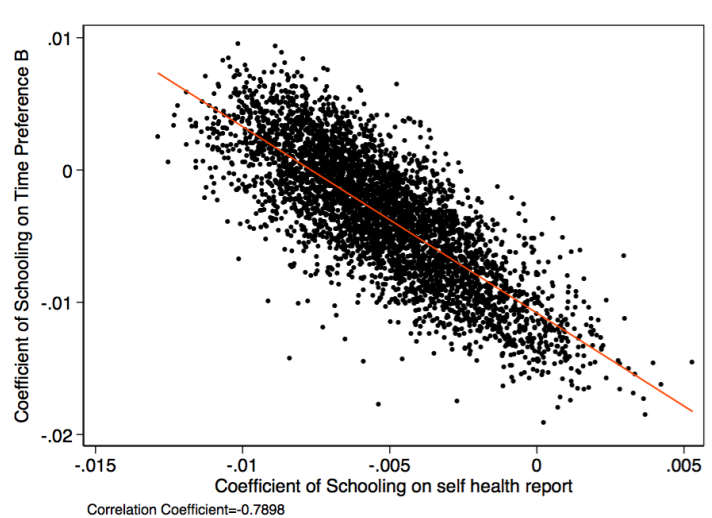

(b) RISK AVERSION

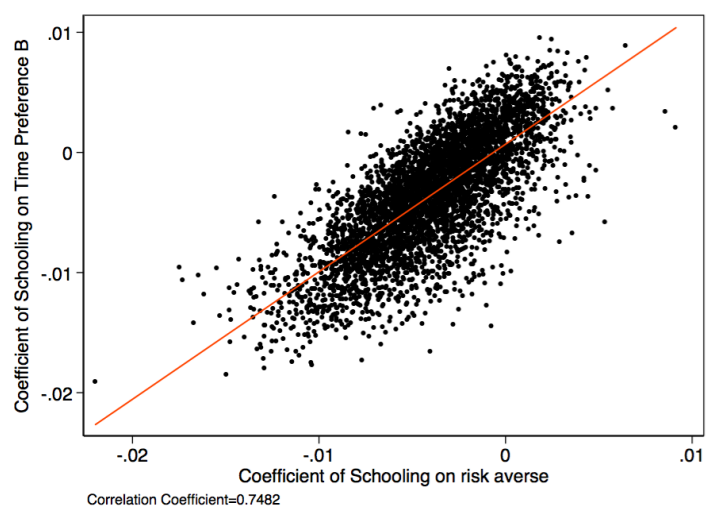

(d) CES-D SCORE

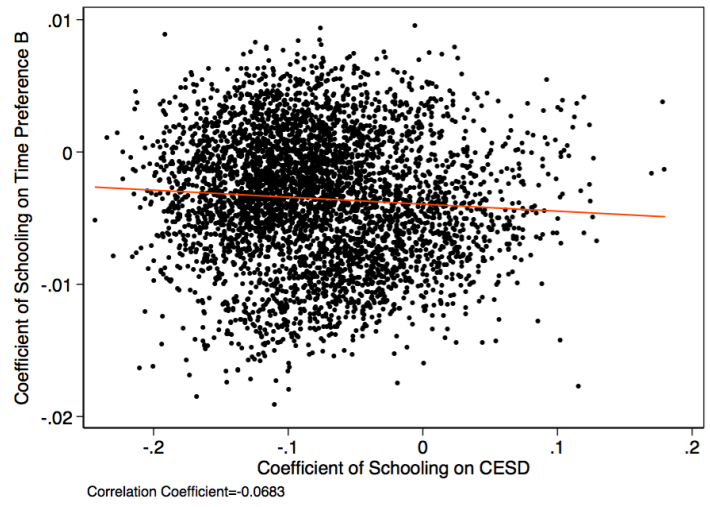

NOTE: The figures plot the conditional correlation coefficients between education and time preference measure B against the correlation between education and the mediator variables for 100 random samples drawn from the main sample with replacement. // 
Table C1: MEDIATION ANALYSIS 1

\begin{tabular}{|c|c|c|c|c|c|c|c|c|}
\hline \multirow[b]{3}{*}{ Years of schooling } & \multicolumn{2}{|c|}{ RAVEN'S TEST SCORE } & \multicolumn{2}{|c|}{ ARITHMETIC SCORE } & \multicolumn{2}{|c|}{ WORD RECALL } & \multicolumn{2}{|c|}{ SERIAL 7'S SCORE } \\
\hline & \multicolumn{8}{|c|}{ DEPENDENT VARIABLE: TIME PREFERENCE A } \\
\hline & $\begin{array}{c}-0.008^{* * *} \\
(0.002)\end{array}$ & $\begin{array}{c}-0.006 * * * \\
(0.001)\end{array}$ & $\begin{array}{c}-0.008^{* * *} * \\
(0.002)\end{array}$ & $\begin{array}{c}-0.006^{* * *} \\
(0.002)\end{array}$ & $\begin{array}{c}-0.007 * * * \\
(0.001)\end{array}$ & $\begin{array}{c}-0.006 \text { *** } \\
(0.001)\end{array}$ & $\begin{array}{c}-0.009 * * * \\
(0.002)\end{array}$ & $\begin{array}{c}-0.008^{* * *} \\
(0.002)\end{array}$ \\
\hline Mechanism variable & & $\begin{array}{c}-0.013 * * * \\
(0.004)\end{array}$ & & $\begin{array}{c}-0.024 * * * \\
(0.003)\end{array}$ & & $\begin{array}{c}-0.004 * * * \\
(0.001)\end{array}$ & & $\begin{array}{c}-0.018^{* * * *} \\
(0.006)\end{array}$ \\
\hline Observations & 10,934 & 10,934 & 10,920 & 10,920 & 18,359 & 18,359 & 9,186 & 9,186 \\
\hline R-squared & 0.099 & 0.102 & 0.099 & 0.103 & 0.078 & 0.079 & 0.104 & 0.106 \\
\hline \multirow[t]{2}{*}{ Mean of DV } & 0.667 & 0.667 & 0.667 & 0.667 & 0.686 & 0.686 & 0.667 & 0.667 \\
\hline & \multicolumn{8}{|c|}{ DEPENDENT VARIABLE: TIME PREFERENCE B } \\
\hline Years of schooling & $\begin{array}{c}-0.005^{* * *} * \\
(0.001)\end{array}$ & $\begin{array}{c}-0.003 * * \\
(0.001)\end{array}$ & $\begin{array}{c}-0.005^{* * *} * \\
(0.001)\end{array}$ & $\begin{array}{c}-0.003^{*} \\
(0.001)\end{array}$ & $\begin{array}{c}-0.005^{* * * *} \\
(0.001)\end{array}$ & $\begin{array}{c}-0.004 * * * \\
(0.001)\end{array}$ & $\begin{array}{c}-0.004 * * * \\
(0.001)\end{array}$ & $\begin{array}{c}-0.004 * * * \\
(0.001)\end{array}$ \\
\hline Mechanism variable & & $\begin{array}{l}-0.007 \\
(0.004)\end{array}$ & & $\begin{array}{c}-0.017 * * * \\
(0.004)\end{array}$ & & $\begin{array}{c}-0.003 * * * \\
(0.001)\end{array}$ & & $\begin{array}{l}-0.008 \\
(0.005)\end{array}$ \\
\hline Observations & 10,934 & 10,934 & 10,920 & 10,920 & 18,359 & 18,359 & 9,186 & 9,186 \\
\hline R-squared & 0.097 & 0.097 & 0.096 & 0.099 & 0.078 & 0.078 & 0.103 & 0.103 \\
\hline \multirow[t]{3}{*}{ Mean of DV } & 0.767 & 0.767 & 0.767 & 0.767 & 0.784 & 0.784 & 0.763 & 0.763 \\
\hline & TOTAI & NCOME & RISK AI & ERSION & SELF $\mathrm{I}$ & EALTH & CES-D & CORE \\
\hline & \multicolumn{8}{|c|}{ DEPENDENT VARIABLE: TIME PREFERENCE A } \\
\hline Years of schooling & $\begin{array}{c}-0.008^{* * * *} \\
(0.001)\end{array}$ & $\begin{array}{c}-0.007 * * * \\
(0.001)\end{array}$ & $\begin{array}{c}-0.007 * * * \\
(0.002)\end{array}$ & $\begin{array}{c}-0.008 * * * \\
(0.002)\end{array}$ & $\begin{array}{c}-0.007 * * * \\
(0.001)\end{array}$ & $\begin{array}{c}-0.007 * * * \\
(0.001)\end{array}$ & $\begin{array}{c}-0.007 * * * \\
(0.001)\end{array}$ & $\begin{array}{c}-0.007 * * * \\
(0.001)\end{array}$ \\
\hline Mechanism variable & & $\begin{array}{c}-0.012 * * \\
(0.005)\end{array}$ & & $\begin{array}{c}0.065 * * * \\
(0.008)\end{array}$ & & $\begin{array}{c}-0.017 \\
(0.014)\end{array}$ & & $\begin{array}{c}-0.002 * * \\
(0.001)\end{array}$ \\
\hline Observations & 12,577 & 12,577 & 12,101 & 12,101 & 18,426 & 18,426 & 18,307 & 18,307 \\
\hline R-squared & 0.097 & 0.097 & 0.095 & 0.098 & 0.078 & 0.078 & 0.078 & 0.078 \\
\hline \multirow[t]{2}{*}{ Mean of DV } & 0.680 & 0.680 & 0.617 & 0.617 & 0.686 & 0.686 & 0.686 & 0.686 \\
\hline & \multicolumn{8}{|c|}{ DEPENDENT VARIABLE: TIME PREFERENCE B } \\
\hline Years of schooling & $\begin{array}{c}-0.006^{* * * *} \\
(0.001)\end{array}$ & $\begin{array}{c}-0.006^{* * * *} \\
(0.001)\end{array}$ & $\begin{array}{c}-0.005 * * * \\
(0.001)\end{array}$ & $\begin{array}{c}-0.005^{* * *} \\
(0.001)\end{array}$ & $\begin{array}{c}-0.005^{* * *} \\
(0.001)\end{array}$ & $\begin{array}{c}-0.005^{* * *} \\
(0.001)\end{array}$ & $\begin{array}{c}-0.005^{* * * *} \\
(0.001)\end{array}$ & $\begin{array}{c}-0.005 * * * \\
(0.001)\end{array}$ \\
\hline Mechanism variable & & $\begin{array}{c}-0.003 \\
(0.004)\end{array}$ & & $\begin{array}{c}0.112 * * * \\
(0.008)\end{array}$ & & $\begin{array}{l}-0.007 \\
(0.013)\end{array}$ & & $\begin{array}{c}-0.003 * * * \\
(0.001)\end{array}$ \\
\hline Observations & 12,577 & 12,577 & 16,763 & 16,763 & 18,426 & 18,426 & 18,307 & 18,307 \\
\hline R-squared & 0.098 & 0.098 & 0.084 & 0.093 & 0.078 & 0.078 & 0.078 & 0.079 \\
\hline Mean of DV & 0.775 & 0.775 & 0.785 & 0.785 & 0.785 & 0.785 & 0.784 & 0.784 \\
\hline Sample & Pooled & Pooled & Pooled & Pooled & Pooled & Pooled & Pooled & Pooled \\
\hline
\end{tabular}

NOTE: $* p<0.1$, ** $p<0.05$, *** $p<0.01$. Higher values of the dependent variables denote higher levels of impatience. Raven test score ranges between 0-8. Arithmetic test measuring mathematical skill scores between 0-5. Word recall score between 0-20. Serial 7 score lies between $0-5$. Total income variable is log of total income earned as wage or business profit, rental income, nonlabor income and retirement pension income. Risk averse is a dummy indicating whether the respondent chose the most risk averse option throughout the risk preference module. Self health is a dummy that takes value 1 if individuals report being in very good health. CESD ranges between 0-30 
Table C2: MEDIATION ANALYSIS 2

\begin{tabular}{|c|c|c|c|c|c|c|c|c|}
\hline $\begin{array}{l}\text { MECHANISM } \\
\text { VARIABLE }\end{array}$ & $\begin{array}{c}\text { RAVEN'S } \\
\text { TEST SCORE }\end{array}$ & $\begin{array}{c}\text { ARITHMETIC } \\
\text { SCORE }\end{array}$ & $\begin{array}{c}\text { WORD } \\
\text { RECALL }\end{array}$ & $\begin{array}{c}\text { SERIAL 7'S } \\
\text { SCORE }\end{array}$ & $\begin{array}{c}\text { TOTAL } \\
\text { INCOME }\end{array}$ & $\begin{array}{c}\text { RISK } \\
\text { AVERSION }\end{array}$ & $\begin{array}{c}\text { SELF } \\
\text { HEALTH }\end{array}$ & $\begin{array}{l}\text { CES-D } \\
\text { SCORE }\end{array}$ \\
\hline & \multicolumn{8}{|c|}{ DEPENDENT VARIABLE: TIME PREFERENCE A } \\
\hline Years of schooling & $\begin{array}{c}-0.006 * * * \\
(0.002)\end{array}$ & $\begin{array}{c}-0.006 * * * \\
(0.002)\end{array}$ & $\begin{array}{c}-0.006 * * * \\
(0.001)\end{array}$ & $\begin{array}{c}-0.008 * * * \\
(0.002)\end{array}$ & $\begin{array}{c}-0.007 * * * \\
(0.001)\end{array}$ & $\begin{array}{c}-0.008 * * * \\
(0.002)\end{array}$ & $\begin{array}{c}-0.007 * * * \\
(0.001)\end{array}$ & $\begin{array}{c}-0.007 * * * \\
(0.001)\end{array}$ \\
\hline Mechanism Variable & $\begin{array}{c}-0.014 * * * \\
(0.003)\end{array}$ & $\begin{array}{c}-0.024 * * * \\
(0.003)\end{array}$ & $\begin{array}{c}-0.004 * * * \\
(0.001)\end{array}$ & $\begin{array}{c}-0.018 * * * \\
(0.004)\end{array}$ & $\begin{array}{c}-0.012 * * * \\
(0.001)\end{array}$ & $\begin{array}{c}0.065 * * * \\
(0.004)\end{array}$ & $\begin{array}{l}-0.017 \\
(0.011)\end{array}$ & $\begin{array}{c}-0.005 * * * \\
(0.001)\end{array}$ \\
\hline Observations & 10,965 & 10,951 & 18,413 & 9,240 & 12,615 & 12,143 & 18,480 & 18,361 \\
\hline Mediation $\%$ of total effect & 0.268 & 0.310 & 0.141 & 0.137 & 0.119 & 0.000 & 0.001 & 0.012 \\
\hline Mean of DV & 0.667 & 0.667 & 0.686 & 0.667 & 0.680 & 0.617 & 0.686 & 0.686 \\
\hline & \multicolumn{8}{|c|}{ DEPENDENT VARIABLE: TIME PREFERENCE B } \\
\hline Years of schooling & $\begin{array}{c}-0.003 * * \\
(0.002)\end{array}$ & $\begin{array}{c}-0.003 * \\
(0.002)\end{array}$ & $\begin{array}{c}-0.004 * * * \\
(0.001)\end{array}$ & $\begin{array}{c}-0.004^{* *} \\
(0.002)\end{array}$ & $\begin{array}{c}-0.006 * * * \\
(0.001)\end{array}$ & $\begin{array}{c}-0.005 * * * \\
(0.001)\end{array}$ & $\begin{array}{c}-0.005 * * * \\
(0.001)\end{array}$ & $\begin{array}{c}-0.005 * * * \\
(0.001)\end{array}$ \\
\hline Mechanism Variable & $\begin{array}{c}-0.007 * * * \\
(0.003)\end{array}$ & $\begin{array}{c}-0.017 * * * \\
(0.003)\end{array}$ & $\begin{array}{c}-0.003 * * * \\
(0.001)\end{array}$ & $\begin{array}{l}-0.007 * \\
(0.004)\end{array}$ & $\begin{array}{c}-0.003 * \\
(0.004)\end{array}$ & $\begin{array}{c}0.112 * * * \\
(0.009)\end{array}$ & $\begin{array}{l}-0.007 \\
(0.009)\end{array}$ & $\begin{array}{c}-0.004 * * * \\
(0.001)\end{array}$ \\
\hline Observations & 10,965 & 10,951 & 18,413 & 9,240 & 12,615 & 16,809 & 18,480 & 18,361 \\
\hline Mediation $\%$ of total effect & 0.265 & 0.402 & 0.137 & 0.124 & 0.039 & 0.073 & 0.000 & 0.016 \\
\hline Mean of DV & 0.767 & 0.767 & 0.784 & 0.763 & 0.775 & 0.785 & 0.785 & 0.784 \\
\hline Sample & Pooled & Pooled & Pooled & Pooled & Pooled & Pooled & Pooled & Pooled \\
\hline
\end{tabular}

NOTE: $* p<0.1, * * p<0.05, * * * p<0.01$. Higher values of the dependent variables denote higher levels of impatience. Raven test score ranges between 0-8. Arithmetic test measuring mathematical skill scores between 0-5. Word recall score between 0-20. Serial 7 score lies between 0-5. Total income variable is log of total income earned as wage or business profit, rental income, nonlabor income and retirement pension income. Risk averse is a dummy indicating whether the respondent chose the most risk averse option throughout the risk preference module. Self health is a dummy that takes value 1 if individuals report being in very good health. CESD ranges between 0-30 